\title{
Systemic Effects of Hemorrhagic Snake Venom Metalloproteinases: Untargeted Peptidomics to Explore the Pathodegradome of Plasma Proteins
}

\author{
Luciana Bertholim ${ }^{1}$, Alison F. A. Chaves ${ }^{1}$, Ana K. Oliveira 1,+ ${ }^{\mathbb{D}}$, Milene C. Menezes ${ }^{1} \mathbb{D}$, Amanda F. Asega ${ }^{1}$, \\ Alexandre K. Tashima ${ }^{2}$, Andre Zelanis ${ }^{3}$ and Solange M. T. Serrano ${ }^{1, *(\mathbb{D}}$ \\ 1 Laboratório de Toxinologia Aplicada, Center of Toxins, Immune-Response and Cell Signalig, CeTICS, \\ Instituto Butantan, São Paulo 05503-900, SP, Brazil; luciana.nasciben@gmail.com (L.B.); \\ alison.chaves@butantan.gov.br (A.F.A.C.); ankaoliv@gmail.com (A.K.O.); \\ menezes.milene@gmail.com (M.C.M.); amanda.asega@gmail.com (A.F.A.) \\ 2 Department of Biochemistry, Escola Paulista de Medicina, Federal University of Sao Paulo, \\ Sao Paulo 04023-901, SP, Brazil; aktashima@unifesp.br \\ 3 Functional Proteomics Laboratory, Department of Science and Technology, Federal University of \\ São Paulo (UNIFESP), 330 Talim St., São José dos Campos 12231-280, SP, Brazil; andre.zelanis@unifesp.br \\ * Correspondence: solange.serrano@butantan.gov.br \\ + Present address: Department of Pathology, University of Virginia School of Medicine, \\ Charlottesville, VA 22908, USA.
}

Citation: Bertholim, L.; Chaves, A.F.A.; Oliveira, A.K.; Menezes, M.C.; Asega, A.F.; Tashima, A.K.; Zelanis, A.; Serrano, S.M.T. Systemic Effects of Hemorrhagic Snake Venom Metalloproteinases: Untargeted Peptidomics to Explore the Pathodegradome of Plasma Proteins. Toxins 2021, 13, 764. https:// doi.org/10.3390/toxins13110764

Received: 19 August 2021

Accepted: 6 October 2021

Published: 28 October 2021

Publisher's Note: MDPI stays neutral with regard to jurisdictional claims in published maps and institutional affiliations.

Copyright: (c) 2021 by the authors. Licensee MDPI, Basel, Switzerland. This article is an open access article distributed under the terms and conditions of the Creative Commons Attribution (CC BY) license (https:// creativecommons.org/licenses/by/ $4.0 /)$.

\begin{abstract}
Hemorrhage induced by snake venom metalloproteinases (SVMPs) is a complex phenomenon that involves capillary disruption and blood extravasation. HF3 (hemorrhagic factor 3) is an extremely hemorrhagic SVMP of Bothrops jararaca venom. Studies using proteomic approaches revealed targets of HF3 among intracellular and extracellular proteins. However, the role of the cleavage of plasma proteins in the context of the hemorrhage remains not fully understood. The main goal of this study was to analyze the degradome of HF3 in human plasma. For this purpose, approaches for the depletion of the most abundant proteins, and for the enrichment of low abundant proteins of human plasma, were used to minimize the dynamic range of protein concentration, in order to assess the proteolytic activity of HF3 on a wide spectrum of proteins, and to detect the degradation products using mass spectrometry-based untargeted peptidomics. The results revealed the hydrolysis products generated by HF3 and allowed the identification of cleavage sites. A total of 61 plasma proteins were identified as cleaved by HF3. Some of these proteins corroborate previous studies, and others are new HF3 targets, including proteins of the coagulation cascade, of the complement system, proteins acting on the modulation of inflammation, and plasma proteinase inhibitors. Overall, the data indicate that HF3 escapes inhibition and sculpts the plasma proteome by degrading key proteins and generating peptides that may act synergistically in the hemorrhagic process.
\end{abstract}

Keywords: Bothrops jararaca; HF3; human plasma; proteolysis; snake venom metalloproteinase

Key Contribution: Application of untargeted peptidomics to identify the degradome of human plasma proteins incubated with a potent hemorrhagic SVMP, HF3 of B. jararaca. Sixty-one proteins were identified as cleaved by HF3; in four types of plasma preparations; and are involved in the systemic effects triggered by the SVMP.

\section{Introduction}

Among the drastic consequences of viperid snakebite envenomation, manifestations of local tissue damage, such as hemorrhage and myonecrosis, may result in permanent tissue damage and sequelae [1,2]. In cases of severe envenomation, bleeding in organs distant from the site of bite, such as the heart, lungs, kidneys, and brain, may also occur [3-5]. Coagulopathy, including procoagulant, blood-clotting, fibrinolytic, and anticoagulant effects, is 
another cause of morbidity and mortality upon viperid snakebite accidents [6,7]. Local and systemic effects of viperid envenomation involve the synergistic effects of snake venom metalloproteinases (SVMPs) on plasma proteins, connective tissue, platelets, and blood vessels. SVMPs are zinc-dependent enzymes classified in the M12B subfamily of metallopeptidases, in which the P-III class protein precursors are comprised pro-, catalytic, disintegrin-like, and cysteine-rich domains [8]. SVMPs target specific capillary basement components, cell surface proteins, and extracellular matrix and plasma proteins, thereby promoting capillary rupture and content extravasation, and resulting in hemostasis disturbance and hemorrhage [8-11].

HF3 is a very potent P-III class SVMP of Bothrops jararaca venom that induces local hemorrhage with minimum hemorrhagic doses of $15 \mathrm{ng}$ on rabbit skin, and $160 \mathrm{ng}$ on mouse skin [12,13]. The precursor of HF3 is composed of 606 amino acid residues, including five putative $\mathrm{N}$-glycosylation sites. The calculated molecular mass of the mature form of HF3 is $46 \mathrm{kDa}$, whereas on SDS-PAGE, it shows a mobility corresponding to a protein of $\sim 70 \mathrm{kDa}$, indicating that it is heavily glycosylated [13,14]. HF3 was shown to degrade proteins of the plasma and extracellular matrix, including fibrinogen, fibronectin, vitronectin, von Willebrand factor, collagens IV and VI, laminin, matrigel, antithrombin III, complement components C3 and C4, prothrombin, and plasminogen in vitro $[9,15]$. Moreover, HF3 showed degradation or limited proteolysis of the proteoglycans aggrecan, brevican, biglycan, decorin, glypican-1, lumican, mimecan, and syndecan-1 [15]. Proteins extracted from the hemorrhagic dorsal skin of mice injected with HF3 were submitted to SDS-PAGE and immunostained with specific anti-proteoglycan antibodies, resulting in the demonstration of in vivo cleavage of biglycan, decorin, glypican-1, lumican, and syndecan-1 [15]. Interestingly, HF3 cleaved the platelet derived growth factor receptor (PDGFR; alpha and beta), and PDGF, in vitro, and both receptor forms were also detected as degraded in vivo in the hemorrhagic process generated by HF3 in the mouse skin [15]. Moreover, the proteolytic activity of HF3 is not affected by plasma proteinase inhibitors, including $\alpha 2$-macroglobulin, which is cleaved by HF3 [16]. The disintegrin-like and cysteine-rich domains of HF3 play a role in its activities upon cells, as reported on their ability to inhibit collagen-induced platelet aggregation, to activate macrophage phagocytosis mediated by $\alpha \mathrm{M} \beta 2$ integrin, and to induce inflammation by increasing leukocyte rolling in the microcirculation $[14,17,18]$.

The potent hemorrhage generated by HF3 on the mouse skin was analyzed using proteomic approaches, which corroborated the hydrolysis of intracellular, extracellular, and plasma proteins, including some proteoglycans [19]. Indeed, the cleavage of proteoglycans suggested a critical role of the destabilization of the mouse skin integrity in the hemorrhagic process generated by HF3, along with the release of pro-inflammatory fragments acting in the imbalance of tissue homeostasis $[15,19]$. Despite the strong evidence of the role of proteolysis in the local hemorrhage promoted by SVMPs, the full substrate repertoire of HF3 is unknown. Recently, we reported positional proteomic studies of HF3 cleavage sites in mouse embryonic fibroblast secreted proteins using terminal amine isotopic labeling of substrates (TAILS), which revealed a number of substrates, including proteins of the extracellular matrix and focal adhesions, and the cysteine protease inhibitor cystatin-C [20]. Proteomic identification of cleavage site specificity (PICS) was also used for identifying cleavage sites and sequence preferences in peptides upon incubation with HF3. Two studies using tryptic libraries of proteins from human plasma [21] and from THP-1 monocytic cells [20] revealed a clear preference for leucine at $\mathrm{P}^{\prime}$ position and the influence of amino acid sequences adjacent to the scissile bond in the substrate specificity of HF3, similarly to other metalloproteinases from viperid venoms [22].

The aim of this study was to gain new insights into the mechanisms of hemorrhage production by HF3 by expanding the analysis of the substrate repertoire of this SVMP on plasma proteins. To this end, approaches for the depletion of the most abundant proteins and for the enrichment of low abundant proteins of the human plasma were used to minimize the dynamic range of protein concentration. In order to assess the proteolytic 
activity of HF3 on a wide spectrum of proteins, we used untargeted peptidomics to detect the degradation products by mass spectrometry.

\section{Results}

The aim of this study was to evaluate the proteolytic activity of HF3 on human plasma proteins. In order to overcome the large protein dynamic range and complexity of human plasma $[23,24]$, four different types of human plasma preparations were compared in in vitro incubations with HF3: whole plasma $[\mathrm{P}(\mathrm{W})]$; plasma depleted of albumin $[\mathrm{P}(\mathrm{Alb}-\mathrm{D})]$; plasma depleted of 20 most abundant proteins [P(20-MAP-D)]; and plasma enriched of low-abundance proteins $[\mathrm{P}(\mathrm{LAP}-\mathrm{E})]$. Further, the resulting degradation products present in the peptide fraction were analyzed by LC-MS/MS and a database search using tools of Mascot in conjunction with the Trans-Proteomic Pipeline (TPP) and PEAKS Studio. An overview of the study is provided in Figure 1, as well as the nomenclature used for the different plasma fractionation methods.

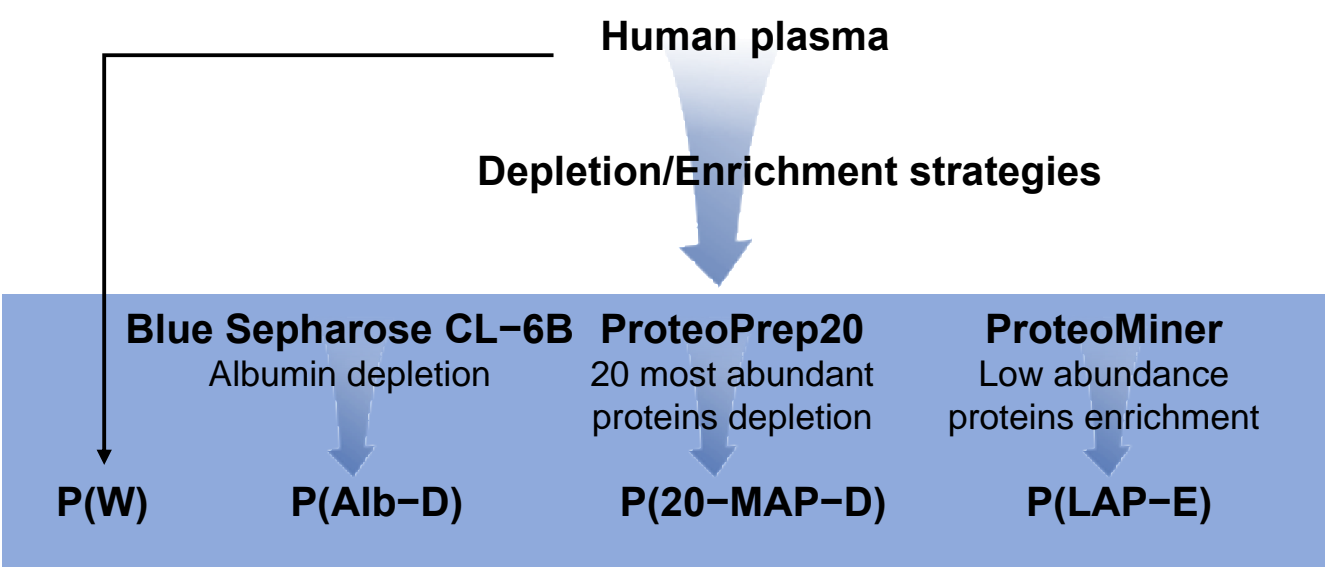

Incubation with HF3 or vehicle $\left(1: 100 w / w, 2 \mathrm{~h}, 37^{\circ} \mathrm{C}\right)$

Protein precipitation $\left(12 \mathrm{~h},-20^{\circ} \mathrm{C}\right)$

Peptide fraction separation (centrifugation $14,000 \mathrm{~g}, 10 \mathrm{~min}, 4^{\circ} \mathrm{C}$ )

$P(W) \quad P(A l b-D) \quad P(L A P-E)$
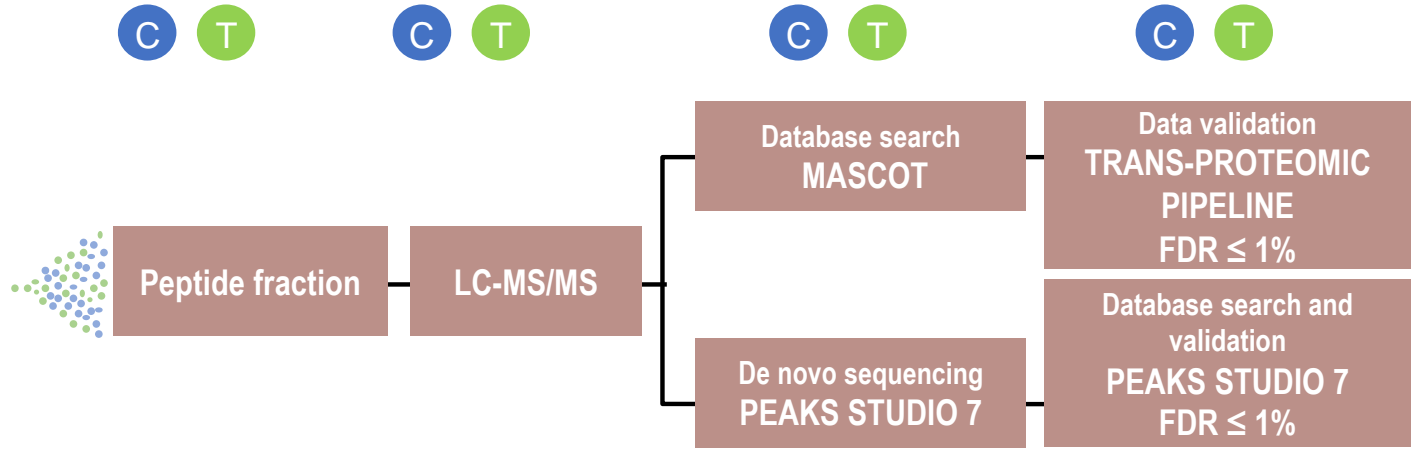

Figure 1. Experimental workflow for the analysis of the proteolytic activity of HF3 on human plasma proteins. Human plasma was depleted of (i) albumin, or (ii) 20 most abundant proteins, or (iii) enriched of low abundant proteins. Whole plasma $[\mathrm{P}(\mathrm{W})]$, albumin-depleted plasma [P(Alb-D)], plasma depleted of the 20 most abundant proteins [P(20-MAP-D)], and plasma enriched of low abundant proteins [P(LAP-E)] were individually incubated with HF3, or vehicle, for $2 \mathrm{~h}$ at 37 ${ }^{\circ} \mathrm{C}$. Peptide fractions from control (C) or HF3-treated (T) samples were obtained and analyzed by LC-MS/MS, and peptides were identified using Mascot in conjunction with the TPP and PEAKS Studio. 
Three individual experiments of incubation of plasma proteins with HF3 were carried out with each of the four types of plasma samples, P(W), P(Alb-D), P(20-MAP-D), and $\mathrm{P}(\mathrm{LAP}-\mathrm{E})$, and the following criteria were used in the untargeted peptidomic analysis to accept a protein as being cleaved by HF3: (i) peptides identified in the control samples were disregarded in the analysis, therefore only proteins that showed peptides identified exclusively in the sample of plasma treated with HF3 were considered; (ii) only proteins identified in at least two experiments were considered.

\subsection{Electrophoretic Profiles of Plasma Samples Incubated with HF3}

As shown in Figure 2, the three methods used for the decomplexation of the plasma proteome to achieve adequate sampling of proteins resulted in distinct electrophoretic profiles, containing proteins of $15-250 \mathrm{kDa}$. The incubation of these plasma samples with HF3 resulted in protein bands that decreased in intensity in the treated plasma in comparison to the control plasma, indicating proteins that may have been degraded by HF3. The bands that increased in intensity in the treated plasma indicated HF3 proteolysis products derived from proteins of higher molecular mass. In the case of $\mathrm{P}(\mathrm{W})$ incubated with HF3, it was possible to observe an increase in the intensity of bands in the region above $225 \mathrm{kDa}$, and a slight variation in the mobility of an intense band in the region of $52 \mathrm{kDa}$. P(Alb-D) treated with HF3 showed a decrease in the intensity of bands of $\sim 140 \mathrm{kDa}$ and above, and also a small alteration in the mobility of the $\sim 52 \mathrm{kDa}$ band. On the other hand, the electrophoretic profile of P(20-MAP-D) treated with HF3 showed only a slight decrease in the intensity of the bands in the region between $80 \mathrm{kDa}$ and $120 \mathrm{kDa}$. However, upon incubation with HF3, P(LAP-E) showed a clear decrease in the intensity of the bands in of $\sim 55 \mathrm{kDa}, 40 \mathrm{kDa}$, and $25 \mathrm{kDa}$, and an increase in the intensity of the bands of $34 \mathrm{kDa}$ and $22 \mathrm{kDa}$.
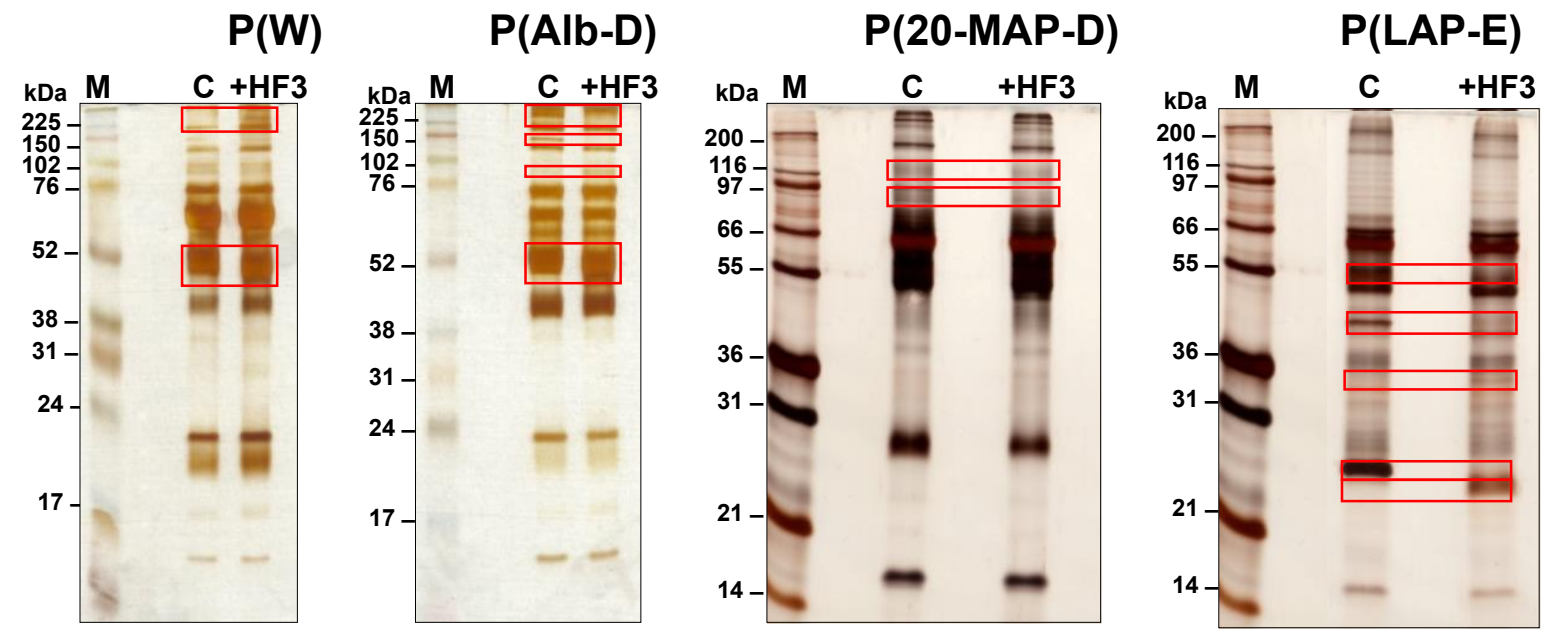

Figure 2. SDS-PAGE profile (12\% SDS-polyacrylamide gel) of plasma samples incubated with HF3. M: molecular mass markers; C: control plasma; +HF3: plasma incubated with HF3. Red rectangles indicate regions showing different staining intensities between the control and HF3-treated plasma. Proteins were stained with silver.

Overall, all electrophoretic profiles indicated differences between control and treated plasma samples, evidencing the proteolytic effect of HF3 on plasma proteins in vitro. Interestingly, the electrophoretic profile of $\mathrm{P}(\mathrm{LAP}-\mathrm{E})$ showed the most significant differences between control and treated samples, possibly due to the fact that the method applied for the enrichment of low abundant proteins of the plasma proteome was more efficient in minimizing the dynamic range of protein concentration, thus enabling a better visualization of the degraded proteins. 


\subsection{Peptidomic Profiling of Plasma Samples Incubated with HF3}

The peptide fractions of control and treated samples of $\mathrm{P}(\mathrm{W}), \mathrm{P}(\mathrm{Alb}-\mathrm{D}), \mathrm{P}(20-\mathrm{MAP}-\mathrm{D})$, and P(LAP-E) were subjected to LC-MS/MS, and analyses of peptide identification and spectra counting were carried out by: (i) a Mascot database search and validation of results using the PeptideProphet and ProteinProphet tools of the TPP platform (the results of this approach were designated as 'Mascot/TPP'); and (ii) de novo sequencing, a database search, and validation of results by Peaks Studio 7 program (the results of this approach were designated as 'PEAKS') (Supplementary Tables S1-S8).

Figure 3 shows Venn diagrams comparing the total numbers of plasma proteins identified as cleaved by HF3 using both identification approaches. The analysis of whole plasma $[\mathrm{P}(\mathrm{W})]$ incubated with HF3 showed 36 proteins as cleaved by HF3 using both identification approaches (Table 1), whereas five proteins were identified exclusively by PEAKS. In the plasma depleted of albumin [P(Alb-D)], we identified 21 proteins cleaved by HF3 using both identification approaches (Table 2), including three proteins exclusively identified by Mascot/TPP, and two proteins exclusively by PEAKS. In the plasma depleted of the 20 most abundant proteins [P(20-MAP-D)], 30 proteins were identified as cleaved by HF3 using both identification approaches (Table 3 ), with one protein identified exclusively by Mascot/TPP, and five by PEAKS. The incubation of HF3 with the plasma enriched of low-abundance proteins $[\mathrm{P}(\mathrm{LAP}-\mathrm{E})]$ revealed 38 substrates by both approaches (Table 4 ), and 16 proteins identified only by PEAKS.

\section{$\mathbf{P}(\mathbf{W})$}

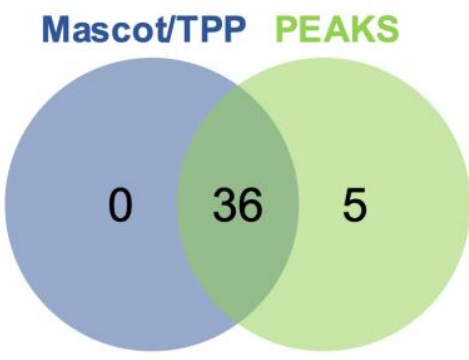

P(20-MAP-D)

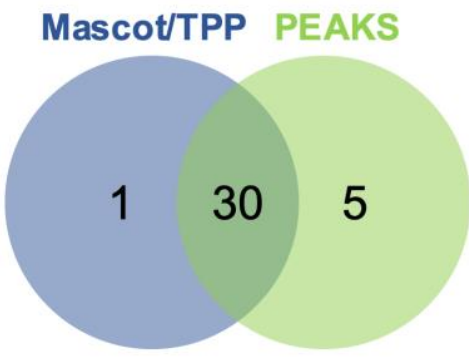

P(Alb-D)

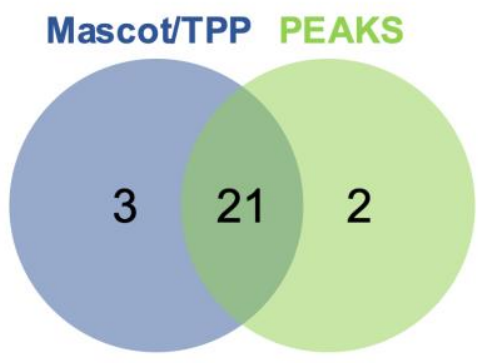

P(LAP-E)

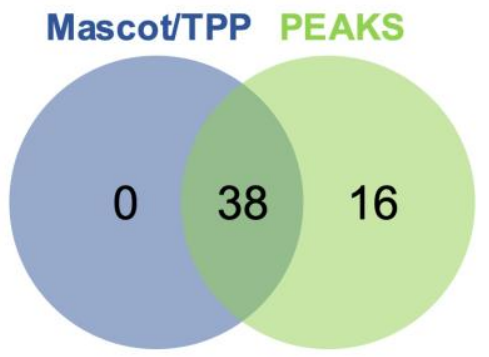

Figure 3. Summary of numbers of plasma proteins identified as degraded by HF3, by LC-MS/MS analysis of the peptide fraction, using four different plasma preparations. Comparison of results obtained using Mascot/TPP and PEAKS Studio 7 for peptide identification. 
Table 1. HF3 substrates revealed by the analysis of $\mathrm{P}(\mathrm{W})$ peptide fraction by LC-MS/MS. Only proteins that showed peptides identified exclusively in the sample of plasma treated with HF3 were considered. The boldface indicates the ten most degraded proteins according to the number of identified spectra.

\begin{tabular}{|c|c|c|c|}
\hline \multirow[b]{2}{*}{ Identification } & \multirow[b]{2}{*}{ Protein } & \multicolumn{2}{|c|}{$\begin{array}{l}\text { Number of Spectra * } \\
\text { (exp. 1/exp. 2/exp. 3) }\end{array}$} \\
\hline & & Mascot/TPP & PEAKS \\
\hline ACTB_HUMAN & Actin cytoplasmic 1 & $0 / 0 / 0$ & $7 / 3 / 0$ \\
\hline A1AT_HUMAN & Alpha-1-antitrypsin & $1 / 0 / 1$ & $6 / 10 / 5$ \\
\hline A2AP_HUMAN & Alpha-2-antiplasmin & $12 / 13 / 13$ & $20 / 24 / 18$ \\
\hline FETUA_HUMAN & Alpha-2-HS-glycoprotein & 75/94/92 & $270 / 437 / 391$ \\
\hline A2MG_HUMAN & Alpha-2-macroglobulin & $2 / 0 / 2$ & $9 / 4 / 8$ \\
\hline APOA1_HUMAN & Apolipoprotein A-I & $9 / 25 / 14$ & $43 / 58 / 50$ \\
\hline APOA2_HUMAN & Apolipoprotein A-II & $13 / 30 / 19$ & $63 / 70 / 60$ \\
\hline APOA4_HUMAN & Apolipoprotein A-IV & $5 / 6 / 7$ & $23 / 21 / 16$ \\
\hline APOC1_HUMAN & Apolipoprotein C-I & $0 / 0 / 0$ & $4 / 5 / 0$ \\
\hline APOC2_HUMAN & Apolipoprotein C-II & $7 / 17 / 11$ & $30 / 41 / 30$ \\
\hline APOC3_HUMAN & Apolipoprotein C-III & $9 / 19 / 13$ & $34 / 43 / 30$ \\
\hline APOE_HUMAN & Apolipoprotein E & $3 / 4 / 3$ & $10 / 9 / 10$ \\
\hline APOF_HUMAN & Apolipoprotein F & $2 / 5 / 3$ & $7 / 11 / 12$ \\
\hline APOL1_HUMAN & Apolipoprotein L1 & $4 / 9 / 5$ & $36 / 38 / 35$ \\
\hline CLUS_HUMAN & Clusterin & $17 / 42 / 29$ & $89 / 108 / 90$ \\
\hline FA5_HUMAN & Coagulation factor $\mathrm{V}$ & $0 / 0 / 0$ & $3 / 0 / 3$ \\
\hline C1R_HUMAN & Complement $\mathrm{C} 1 \mathrm{r}$ subcomponent & $1 / 2 / 2$ & $18 / 15 / 15$ \\
\hline C1S_HUMAN & Complement $\mathrm{C} 1$ s subcomponent & $3 / 3 / 2$ & $26 / 20 / 16$ \\
\hline CO3_HUMAN & Complement C3 & $9 / 18 / 16$ & $20 / 26 / 21$ \\
\hline CO4A_HUMAN & Complement C4-A & $19 / 30 / 24$ & $61 / 76 / 67$ \\
\hline CO9_HUMAN & Complement component C9 & $0 / 2 / 1$ & $3 / 4 / 0$ \\
\hline CFAH_HUMAN & Complement factor $\mathrm{H}$ & $1 / 2 / 0$ & $3 / 2 / 0$ \\
\hline FIBA_HUMAN & Fibrinogen alpha chain & $126 / 221 / 163$ & $369 / 602 / 462$ \\
\hline FIBB_HUMAN & Fibrinogen beta chain & $16 / 52 / 32$ & $39 / 53 / 45$ \\
\hline FINC_HUMAN & Fibronectin & $7 / 12 / 6$ & $29 / 29 / 22$ \\
\hline GELS_HUMAN & Gelsolin & $5 / 8 / 7$ & $28 / 21 / 25$ \\
\hline HRG_HUMAN & Histidine-rich glycoprotein & $10 / 10 / 8$ & $24 / 55 / 39$ \\
\hline H2BFS_HUMAN & Histone H2B type F-S & $0 / 0 / 0$ & $4 / 1 / 0$ \\
\hline IGHG1_HUMAN & Ig gamma- 1 chain $C$ region & $0 / 5 / 1$ & $6 / 8 / 7$ \\
\hline IGHM_HUMAN & Ig mu chain $C$ region & $2 / 5 / 2$ & $6 / 6 / 6$ \\
\hline ITIH1_HUMAN & Inter-alpha-trypsin inhibitor heavy chain $\mathrm{H} 1$ & $6 / 5 / 6$ & $17 / 17 / 19$ \\
\hline ITIH2_HUMAN & Inter-alpha-trypsin inhibitor heavy chain $\mathrm{H} 2$ & $51 / 92 / 79$ & $204 / 230 / 224$ \\
\hline ITIH3_HUMAN & Inter-alpha-trypsin inhibitor heavy chain $\mathrm{H} 3$ & $1 / 2 / 1$ & $6 / 4 / 5$ \\
\hline ITIH4_HUMAN & Inter-alpha-trypsin inhibitor heavy chain $\mathrm{H} 4$ & $24 / 37 / 28$ & 93/103/94 \\
\hline KNG1_HUMAN & Kininogen-1 & $8 / 8 / 10$ & $33 / 21 / 30$ \\
\hline PEDF_HUMAN & Pigment epithelium-derived factor & $3 / 4 / 3$ & $5 / 5 / 4$ \\
\hline PZP_HUMAN & Pregnancy zone protein & $0 / 1 / 2$ & $5 / 5 / 5$ \\
\hline
\end{tabular}


Table 1. Cont.

\begin{tabular}{cccc}
\hline & & \multicolumn{2}{c}{$\begin{array}{c}\text { Number of Spectra * } \\
\text { (exp. 1/exp. 2/exp. 3) }\end{array}$} \\
\hline Identification & Protein & Mascot/TPP & PEAKS \\
\hline THRB_HUMAN & Prothrombin & $\mathbf{1 7 / 2 5 / 2 0}$ & $\mathbf{6 3 / 6 2 / 6 5}$ \\
\hline ALBU_HUMAN & Serum albumin & $0 / 0 / 0$ & $0 / 3 / 2$ \\
\hline TTHY_HUMAN & Transthyretin & $6 / 17 / 17$ & $43 / 43 / 43$ \\
\hline VTNC_HUMAN & Vitronectin & $\mathbf{1 8 / 3 1 / 2 4}$ & $74 / 78 / 71$ \\
\hline
\end{tabular}

\footnotetext{
* Only spectra identified exclusively in the HF3-treated samples were considered.
}

Table 2. HF3 substrates revealed by the analysis of $\mathrm{P}(\mathrm{Alb}-\mathrm{D})$ peptide fraction by LC-MS/MS. Only proteins that showed peptides identified exclusively in the sample of plasma treated with HF3 were considered. The boldface indicates the ten most degraded proteins according to the number of identified spectra.

\begin{tabular}{|c|c|c|c|}
\hline \multirow[b]{2}{*}{ Identification } & \multirow[b]{2}{*}{ Protein } & \multicolumn{2}{|c|}{$\begin{array}{l}\text { Number of Spectra * } \\
\text { (exp. 1/exp. 2/exp. 3) }\end{array}$} \\
\hline & & Mascot/TPP & PEAKS \\
\hline ACTG_HUMAN & Actin cytoplasmic 1 & $0 / 0 / 0$ & $1 / 0 / 1$ \\
\hline A1AT_HUMAN & Alpha-1-antitrypsin & 1/10/11 & $16 / 24 / 25$ \\
\hline A2AP_HUMAN & Alpha-2-antiplasmin & 10/12/11 & $17 / 18 / 20$ \\
\hline FETUA_HUMAN & Alpha-2-HS-glycoprotein & $84 / 109 / 117$ & $219 / 226 / 230$ \\
\hline APOA1_HUMAN & Apolipoprotein A-I & $13 / 0 / 1$ & $33 / 8 / 6$ \\
\hline APOA2_HUMAN & Apolipoprotein A-II & $5 / 3 / 1$ & $17 / 13 / 11$ \\
\hline APOA4_HUMAN & Apolipoprotein A-IV & $8 / 5 / 7$ & $13 / 13 / 15$ \\
\hline APOC2_HUMAN & Apolipoprotein C-II & $4 / 3 / 2$ & $11 / 8 / 8$ \\
\hline APOC3_HUMAN & Apolipoprotein C-III & $6 / 12 / 10$ & $21 / 25 / 27$ \\
\hline APOE_HUMAN & Apolipoprotein E & $3 / 2 / 2$ & $2 / 4 / 4$ \\
\hline APOL1_HUMAN & Apolipoprotein L1 & $0 / 4 / 1$ & $4 / 8 / 10$ \\
\hline CERU_HUMAN & Ceruloplasmin & $0 / 2 / 3$ & $2 / 6 / 9$ \\
\hline CLUS_HUMAN & Clusterin & $1 / 2 / 2$ & $5 / 16 / 12$ \\
\hline CO3_HUMAN & Complement C3 & $0 / 2 / 4$ & $0 / 2 / 8$ \\
\hline FIBA_HUMAN & Fibrinogen alpha chain & $0 / 3 / 14$ & $2 / 13 / 41$ \\
\hline FIBB_HUMAN & Fibrinogen beta chain & $7 / 14 / 20$ & $13 / 20 / 28$ \\
\hline FINC_HUMAN & Fibronectin & $0 / 1 / 2$ & $0 / 0 / 0$ \\
\hline GPX3_HUMAN & Glutathione peroxidase 3 & $0 / 0 / 0$ & $5 / 7 / 0$ \\
\hline IGHG1_HUMAN & Ig gamma-1 chain $\mathrm{C}$ region & $2 / 1 / 0$ & $0 / 0 / 0$ \\
\hline ITIH2_HUMAN & Inter-alpha-trypsin inhibitor heavy chain $\mathrm{H} 2$ & 2/7/18 & $7 / 26 / 42$ \\
\hline ITIH4_HUMAN & Inter-alpha-trypsin inhibitor heavy chain H4 & $0 / 4 / 4$ & $0 / 8 / 7$ \\
\hline MGAP_HUMAN & Isoform 3 of MAX gene-associated protein & $4 / 2 / 0$ & $0 / 0 / 0$ \\
\hline KNG1_HUMAN & Kininogen-1 & $1 / 2 / 1$ & $2 / 8 / 6$ \\
\hline THRB_HUMAN & Prothrombin & $1 / 2 / 5$ & $2 / 6 / 12$ \\
\hline PON1_HUMAN & Serum paraoxonase/arylesterase 1 & $7 / 15 / 21$ & $27 / 36 / 52$ \\
\hline TTHY_HUMAN & Transthyretin & $27 / 33 / 34$ & $44 / 57 / 68$ \\
\hline
\end{tabular}

* Only spectra identified exclusively in the HF3-treated samples were considered. 
Table 3. HF3 substrates revealed by the analysis of P(20-MAP-D) peptide fraction by LC-MS/MS. Only proteins that showed peptides identified exclusively in the sample of plasma treated with HF3 were considered. The boldface indicates the ten most degraded proteins according to the number of identified spectra.

\begin{tabular}{|c|c|c|c|}
\hline \multirow[b]{2}{*}{ Identification } & \multirow[b]{2}{*}{ Protein } & \multicolumn{2}{|c|}{$\begin{array}{l}\text { Number of Spectra * } \\
\text { (exp. 1/exp. 2/exp. 3) }\end{array}$} \\
\hline & & Mascot/TPP & PEAKS \\
\hline ACTB_HUMAN & Actin cytoplasmic 1 & $6 / 0 / 2$ & $18 / 0 / 2$ \\
\hline A2AP_HUMAN & Alpha-2-antiplasmin & $70 / 28 / 20$ & $81 / 39 / 30$ \\
\hline FETUA_HUMAN & Alpha-2-HS-glycoprotein & 270/150/134 & $454 / 232 / 245$ \\
\hline A2MG_HUMAN & Alpha-2-macroglobulin & $5 / 4 / 3$ & $7 / 6 / 4$ \\
\hline APOA1_HUMAN & Apolipoprotein A-I & $69 / 39 / 36$ & $91 / 58 / 62$ \\
\hline APOA2_HUMAN & Apolipoprotein A-II & $39 / 19 / 21$ & $56 / 30 / 37$ \\
\hline APOA4_HUMAN & Apolipoprotein A-IV & 28/48/15 & $56 / 71 / 31$ \\
\hline APOC1_HUMAN & Apolipoprotein C-I & $0 / 0 / 0$ & $2 / 2 / 0$ \\
\hline APOC2_HUMAN & Apolipoprotein C-II & $39 / 4 / 10$ & $46 / 6 / 18$ \\
\hline APOC3_HUMAN & Apolipoprotein C-III & $55 / 9 / 10$ & $68 / 14 / 17$ \\
\hline APOE_HUMAN & Apolipoprotein E & $4 / 9 / 2$ & $8 / 11 / 7$ \\
\hline APOF_HUMAN & Apolipoprotein F & $17 / 7 / 2$ & $26 / 4 / 0$ \\
\hline APOL1_HUMAN & Apolipoprotein L1 & $8 / 4 / 7$ & $8 / 3 / 19$ \\
\hline CBPB2_HUMAN & Carboxypeptidase B2 & $0 / 0 / 0$ & $1 / 0 / 4$ \\
\hline CLUS_HUMAN & Clusterin & $5 / 2 / 8$ & $10 / 4 / 30$ \\
\hline F13A_HUMAN & Coagulation factor XIII A chain & $5 / 0 / 1$ & $5 / 0 / 1$ \\
\hline C1R_HUMAN & Complement $\mathrm{C} 1 \mathrm{r}$ subcomponent & $5 / 0 / 2$ & $0 / 0 / 0$ \\
\hline CO3_HUMAN & Complement C3 & $5 / 2 / 3$ & $5 / 2 / 6$ \\
\hline CO4A_HUMAN & Complement C4-A & $6 / 0 / 10$ & $9 / 0 / 15$ \\
\hline ECM1_HUMAN & Extracellular matrix protein 1 & $0 / 0 / 0$ & $4 / 3 / 0$ \\
\hline FIBA_HUMAN & Fibrinogen alpha chain & $159 / 50 / 83$ & $162 / 0 / 122$ \\
\hline FIBB_HUMAN & Fibrinogen beta chain & $31 / 38 / 14$ & $34 / 44 / 17$ \\
\hline FINC_HUMAN & Fibronectin & $4 / 1 / 8$ & $6 / 5 / 22$ \\
\hline GELS_HUMAN & Gelsolin & $49 / 18 / 14$ & $68 / 23 / 42$ \\
\hline HRG_HUMAN & Histidine-rich glycoprotein & $2 / 6 / 14$ & $5 / 7 / 29$ \\
\hline IGHG1_HUMAN & Ig gamma-1 chain $C$ region & $4 / 0 / 9$ & $4 / 0 / 12$ \\
\hline ITIH2_HUMAN & Inter-alpha-trypsin inhibitor heavy chain $\mathrm{H} 2$ & 20/18/34 & $31 / 23 / 69$ \\
\hline ITIH3_HUMAN & Inter-alpha-trypsin inhibitor heavy chain H3 & $0 / 0 / 0$ & $2 / 0 / 9$ \\
\hline ITIH4_HUMAN & Inter-alpha-trypsin inhibitor heavy chain $\mathrm{H} 4$ & $131 / 44 / 38$ & $174 / 56 / 80$ \\
\hline FIBG_HUMAN & Isoform Gamma-A of Fibrinogen gamma chain & $2 / 19 / 0$ & $3 / 19 / 0$ \\
\hline KNG1_HUMAN & Kininogen-1 & $7 / 1 / 3$ & $17 / 3 / 9$ \\
\hline THRB_HUMAN & Prothrombin & $1 / 2 / 23$ & $1 / 2 / 61$ \\
\hline SAA4_HUMAN & Serum amyloid A-4 protein & $0 / 0 / 0$ & $7 / 1 / 0$ \\
\hline TETN_HUMAN & Tetranectin & $5 / 2 / 5$ & $5 / 2 / 6$ \\
\hline TTHY_HUMAN & Transthyretin & $9 / 2 / 10$ & $10 / 2 / 15$ \\
\hline VTNC_HUMAN & Vitronectin & $33 / 9 / 11$ & $43 / 12 / 15$ \\
\hline
\end{tabular}

* Only spectra identified exclusively in the HF3-treated samples were considered. 
Table 4. HF3 substrates revealed by the analysis of P(LAP-E) peptide fraction by LC-MS/MS. Only proteins that showed peptides identified exclusively in the sample of plasma treated with HF3 were considered. The boldface indicates the ten most degraded proteins according to the number of identified spectra.

\begin{tabular}{|c|c|c|c|}
\hline \multirow[b]{2}{*}{ Identification } & \multirow[b]{2}{*}{ Protein } & \multicolumn{2}{|c|}{$\begin{array}{c}\text { Number of Spectra * } \\
(\exp 1 / \exp 2 / \exp 3)\end{array}$} \\
\hline & & Mascot/TPP & PEAKS \\
\hline A1AT_HUMAN & Alpha-1-antitrypsin & $3 / 15 / 1$ & $5 / 18 / 3$ \\
\hline A2AP_HUMAN & Alpha-2-antiplasmin & $1 / 2 / 0$ & $2 / 4 / 0$ \\
\hline FETUA_HUMAN & Alpha-2-HS-glycoprotein & $32 / 31 / 30$ & $51 / 60 / 49$ \\
\hline APOA1_HUMAN & Apolipoprotein A-I & $80 / 127 / 17$ & $171 / 258 / 37$ \\
\hline APOA2_HUMAN & Apolipoprotein A-II & $37 / 69 / 20$ & $56 / 132 / 26$ \\
\hline APOA4_HUMAN & Apolipoprotein A-IV & $52 / 86 / 11$ & $124 / 201 / 20$ \\
\hline APOC1_HUMAN & Apolipoprotein C-I & $11 / 17 / 0$ & $34 / 45 / 2$ \\
\hline APOC2_HUMAN & Apolipoprotein C-II & $22 / 21 / 5$ & $27 / 32 / 9$ \\
\hline APOC3_HUMAN & Apolipoprotein C-III & $19 / 51 / 5$ & $43 / 88 / 11$ \\
\hline APOE_HUMAN & Apolipoprotein E & $29 / 9 / 4$ & $57 / 30 / 13$ \\
\hline APOF_HUMAN & Apolipoprotein F & $1 / 2 / 0$ & $1 / 2 / 0$ \\
\hline APOL1_HUMAN & Apolipoprotein L1 & $0 / 0 / 0$ & $0 / 3 / 2$ \\
\hline C4BPA_HUMAN & C4b-binding protein alpha chain & $0 / 0 / 0$ & $3 / 5 / 0$ \\
\hline CBPB2_HUMAN & Carboxypeptidase B2 & $1 / 0 / 1$ & $1 / 0 / 1$ \\
\hline CLUS_HUMAN & Clusterin & $1 / 18 / 0$ & $7 / 49 / 0$ \\
\hline CO1A2_HUMAN & Collagen alpha-2(I) chain & $0 / 0 / 0$ & $1 / 0 / 1$ \\
\hline COL11_HUMAN & Collectin-11 & $0 / 2 / 1$ & $3 / 5 / 2$ \\
\hline C1QB_HUMAN & Complement $\mathrm{C} 1 \mathrm{q}$ subcomponent subunit B & $0 / 0 / 0$ & $1 / 0 / 1$ \\
\hline C1S_HUMAN & Complement $\mathrm{C} 1 \mathrm{~s}$ subcomponent & $0 / 0 / 0$ & $1 / 3 / 0$ \\
\hline CO3_HUMAN & Complement C3 & $8 / 9 / 7$ & $13 / 22 / 21$ \\
\hline CO4A_HUMAN & Complement C4-A & $4 / 14 / 4$ & $17 / 30 / 11$ \\
\hline CFAH_HUMAN & Complement factor $\mathrm{H}$ & $0 / 3 / 2$ & $0 / 7 / 2$ \\
\hline FHR1_HUMAN & Complement factor H-related protein 1 & $0 / 0 / 0$ & $3 / 8 / 0$ \\
\hline FIBA_HUMAN & Fibrinogen alpha chain & $82 / 141 / 40$ & $149 / 241 / 63$ \\
\hline FIBB_HUMAN & Fibrinogen beta chain & $160 / 29 / 9$ & $84 / 50 / 7$ \\
\hline FINC_HUMAN & Fibronectin & $4 / 7 / 6$ & $4 / 10 / 15$ \\
\hline FCN2_HUMAN & Ficolin-2 & $1 / 2 / 0$ & $2 / 4 / 0$ \\
\hline LG3BP_HUMAN & Galectin-3-binding protein & $0 / 0 / 0$ & $2 / 2 / 0$ \\
\hline GELS_HUMAN & Gelsolin & $3 / 2 / 1$ & $5 / 6 / 2$ \\
\hline GPX3_HUMAN & Glutathione peroxidase 3 & $1 / 0 / 1$ & $1 / 2 / 1$ \\
\hline HRG_HUMAN & Histidine-rich glycoprotein & $0 / 0 / 0$ & $1 / 5 / 0$ \\
\hline HABP2_HUMAN & Hyaluronan-binding protein 2 & $2 / 3 / 0$ & $2 / 6 / 0$ \\
\hline IGHG1_HUMAN & Ig gamma- 1 chain $C$ region & $0 / 2 / 4$ & $0 / 6 / 10$ \\
\hline IGKC_HUMAN & Ig kappa chain $C$ region & $1 / 9 / 0$ & $3 / 14 / 1$ \\
\hline KV309_HUMAN & Ig kappa chain V-III region VG (Fragment) & $0 / 0 / 0$ & $1 / 6 / 0$ \\
\hline KV402_HUMAN & Ig kappa chain V-IV region Len & $0 / 0 / 0$ & $1 / 2 / 0$ \\
\hline
\end{tabular}


Table 4. Cont.

\begin{tabular}{|c|c|c|c|}
\hline \multirow[b]{2}{*}{ Identification } & \multirow[b]{2}{*}{ Protein } & \multicolumn{2}{|c|}{$\begin{array}{c}\text { Number of Spectra * } \\
(\exp 1 / \exp 2 / \exp 3)\end{array}$} \\
\hline & & Mascot/TPP & PEAKS \\
\hline LV101_HUMAN & Ig lambda chain V-I region $\mathrm{V}$ & $0 / 0 / 0$ & $1 / 3 / 2$ \\
\hline LV403_HUMAN & Ig lambda chain V-IV region Hil & $0 / 0 / 0$ & $0 / 3 / 1$ \\
\hline LAC2_HUMAN & Ig lambda-2 chain $\mathrm{C}$ regions & $3 / 4 / 0$ & $8 / 12 / 9$ \\
\hline IGLL5_HUMAN & Immunoglobulin lambda-like polypeptide 5 & $0 / 0 / 0$ & $0 / 8 / 12$ \\
\hline ITIH1_HUMAN & Inter-alpha-trypsin inhibitor heavy chain $\mathrm{H} 1$ & $2 / 4 / 0$ & $3 / 8 / 0$ \\
\hline ITIH2_HUMAN & Inter-alpha-trypsin inhibitor heavy chain $\mathrm{H} 2$ & $23 / 24 / 2$ & $35 / 42 / 3$ \\
\hline ITIH4_HUMAN & Inter-alpha-trypsin inhibitor heavy chain $\mathrm{H} 4$ & $10 / 7 / 2$ & $21 / 20 / 8$ \\
\hline FIBG_HUMAN & Isoform Gamma-A of fibrinogen gamma chain & $8 / 9 / 0$ & $19 / 25 / 0$ \\
\hline KNG1_HUMAN & Kininogen-1 & $2 / 3 / 0$ & $6 / 6 / 3$ \\
\hline PLMN_HUMAN & Plasminogen & $0 / 0 / 0$ & $1 / 6 / 0$ \\
\hline PRAP1_HUMAN & Proline-rich acidic protein 1 & $0 / 0 / 0$ & $4 / 1 / 2$ \\
\hline THRB_HUMAN & Prothrombin & $7 / 20 / 5$ & $21 / 43 / 12$ \\
\hline ALBU_HUMAN & Serum albumin & $1 / 10 / 1$ & $2 / 25 / 6$ \\
\hline SAA4_HUMAN & Serum amyloid A-4 protein & $4 / 3 / 0$ & $14 / 11 / 1$ \\
\hline TTHY_HUMAN & Transthyretin & $2 / 5 / 0$ & $7 / 13 / 3$ \\
\hline PROC_HUMAN & Vitamin K-dependent protein C & $0 / 0 / 0$ & $0 / 1 / 1$ \\
\hline PROS_HUMAN & Vitamin K-dependent protein S & $2 / 1 / 0$ & $4 / 5 / 1$ \\
\hline VTNC_HUMAN & Vitronectin & $19 / 43 / 13$ & $41 / 85 / 20$ \\
\hline
\end{tabular}

* Only spectra identified exclusively in the HF3-treated samples were considered.

Regarding the different methods of depletion of abundant plasma proteins and enrichment of low-abundant proteins, the four-way Venn diagrams displayed in Figure 4 show that the analysis of the peptide fraction of P(LAP-E) provided a higher number of identified HF3 substrates, with 11 substrates indicated by the approach of Mascot/TPP, and 19 substrates indicated by PEAKS. Unexpectedly, the analysis of $\mathrm{P}(\mathrm{W})$ incubated with HF3 also provided results on HF3 substrates which were identified exclusively by this method (six substrates by the Mascot/TPP identification approach, and seven substrates by PEAKS), however, it is worth mentioning that the initial amount of proteins used in the incubation of $\mathrm{P}(\mathrm{W})$ with HF3 was higher $(200 \mu \mathrm{g})$ compared to $50 \mu \mathrm{g}$ for $\mathrm{P}(\mathrm{Alb}-\mathrm{D})$, $\mathrm{P}(20-\mathrm{MAP}-\mathrm{D})$, and $\mathrm{P}(\mathrm{LAP}-\mathrm{E})$. This result can be attributed to the fact that there was less manipulation of the whole plasma sample compared to other approaches, which involved at least one more protein depletion/enrichment step, performed separately (biological replicates), before incubation with the proteinase.

In general, in each method of preparation of human plasma for incubation with HF3, most proteins considered as a target of HF3 for proteolysis were identified by both bioinformatics approaches used, reinforcing the results (Figure 4). Interestingly, both approaches resulted in a higher number of substrates identified in the $\mathrm{P}(\mathrm{W})$ and $\mathrm{P}(\mathrm{LAP}-\mathrm{E})$ plasma samples. Moreover, although the PEAKS approach revealed a higher number of HF3 substrates (70), 53 proteins were identified by both bioinformatics approaches. 

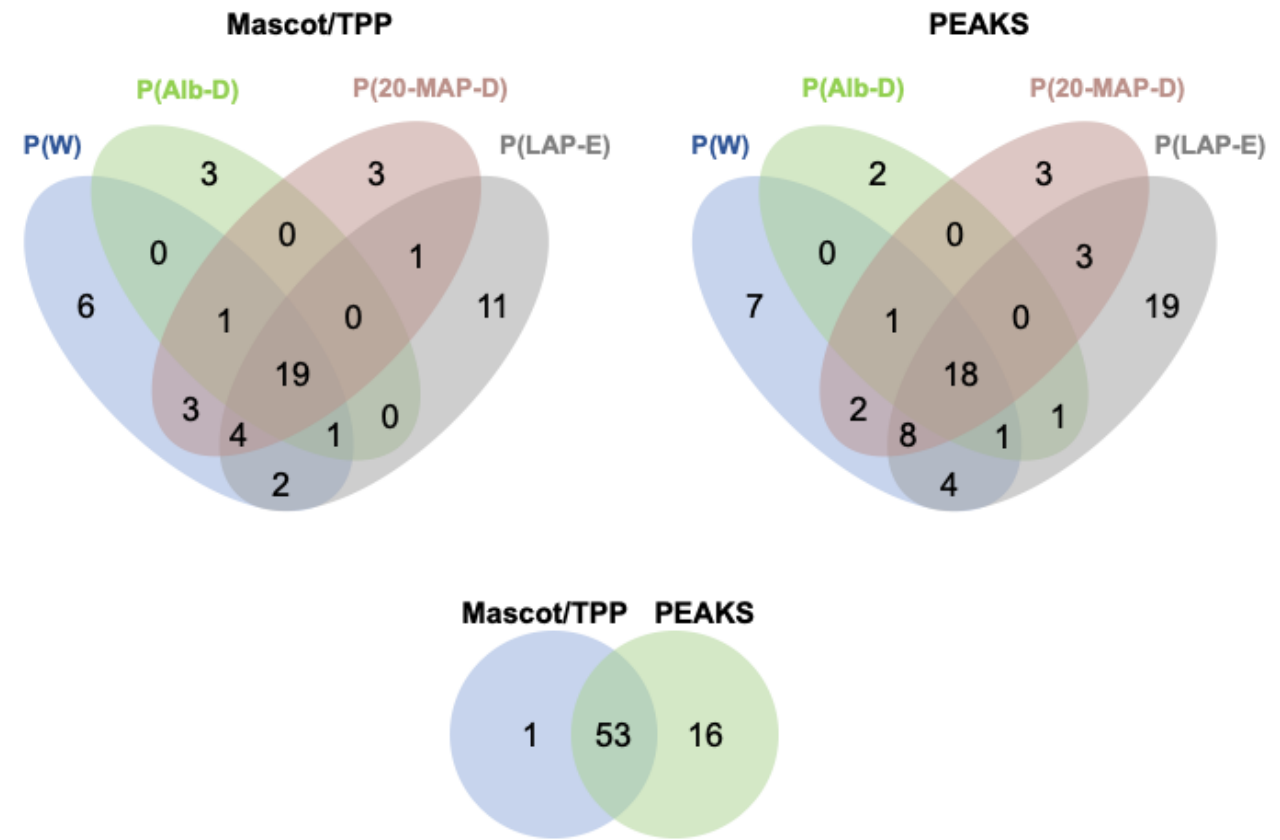

Figure 4. Summary of proteins identified as HF3 substrates. Upper panels: Four-way Venn diagrams of substrate identification using four samples of human plasma, and two methods of protein identification. Lower panel: Summary of proteins identified by each method of protein identification.

\subsection{Proteins Degraded by HF3 in the Human Plasma}

Table 1 shows the list of 41 proteins identified as substrates of HF3 in the P(W) sample. The ten most degraded substrates are proteins involved in functions in the coagulation cascade, complement system, protein transport, and proteinase inhibition.

The identification of substrates of HF3 in the plasma depleted of albumin resulted in only 26 proteins (Table 2). The ten most degraded substrates are proteins involved in functions in the coagulation cascade, complement system, lipid transport, hormone transport, and proteinase inhibition.

In the plasma depleted of the 20 most abundant proteins, 36 proteins were identified as degraded by HF3 (Table 3), whereas in the plasma submitted to enrichment of the low-abundant proteins, 54 proteins were detected as cleaved by HF3 (Table 4). Despite the higher number of substrates identified in the latter, the ten most degraded proteins in both types of plasma preparations were nearly the same. Considering the bioinformatics approaches applied for peptide identification, overall, when using PEAKS, higher numbers of spectra were identified for all degraded proteins.

Overall, a total of 61 proteins (Table 5) were detected as cleaved by HF3, including 18 that were identified in all types of plasma preparations: alpha-2-antiplasmin; alpha-2-HSglycoprotein; apolipoproteins A-I, A-II, A-IV, C-II, C-III, E, and L1; clusterin; complement C3; fibrinogen alpha and beta chains; inter-alpha-trypsin inhibitor heavy chains $\mathrm{H} 2$ and H4; kininogen-1; prothrombin; and transthyretin. 
Table 5. 61 proteins identified as cleaved by HF3 in human plasma.

\begin{tabular}{|c|c|}
\hline Actin Cytoplasmic-1 & Fibrinogen \\
\hline Alpha-1-antitrypsin & Fibronectin \\
\hline Alpha-2-antiplasmin & Ficolin-2 \\
\hline Alpha-2-HS-glycoprotein & Galectin-3-binding protein \\
\hline Apha-2-macroglobulin & Gelsolin \\
\hline Apolipoprotein A-I & Glutathione peroxidase 3 \\
\hline Apolipoprotein A-II & Histidine-rich glycoprotein \\
\hline Apolipoprotein A-IV & Histone H2B type F-S \\
\hline Apolipoprotein C-I & Hyaluronan-binding protein 2 \\
\hline Apolipoprotein C-II & Ig gamma \\
\hline Apolipoprotein C-IIII & Ig kappa \\
\hline Apolipoprotein E & Ig lambda \\
\hline Apolipoprotein F & Ig mu chain $\mathrm{C}$ region \\
\hline Apolipoprotein L1 & Ig lambda-like polypeptide 5 \\
\hline C4b-binding protein alpha chain & Inter-alpha-trypsin inhibitor $\mathrm{H} 1-\mathrm{H} 4$ chains \\
\hline Carboxypeptidade B2 & Isoform 3 of MAX gene-associated protein \\
\hline Ceruloplasmin & Kininogen \\
\hline Clusterin & Pigment ephitelium-derived factor \\
\hline Coagulation factor $\mathrm{V}$ & Plasminogen \\
\hline Coagulation factor XIII A chain & Pregnancy zone protein \\
\hline Collagen alpha-2(I) chain & Proline-rich acidic protein 1 \\
\hline Collectin 11 & Prothrombin \\
\hline Complement C1q subcomponent subunit B & Serum albumin \\
\hline Complement $\mathrm{C} 1 \mathrm{r}$ subcomponent & Serum amyloid A-4 protein \\
\hline Complement C1s subcomponent & Serum paraoxonase/arylesterase 1 \\
\hline Complement component C3 & Tetranectin \\
\hline Complement component C4-A & Transthyretin \\
\hline Complement component C9 & Vitamin K-dependent protein C \\
\hline Complement factor $\mathrm{H}$ & Vitamin K-dependent protein S \\
\hline Complement factor H-related protein & Vitronectin \\
\hline Extracellular matrix protein 1 & \\
\hline
\end{tabular}

We further investigated the newly identified proteins as HF3 substrates in the human plasma. For this analysis, we selected some proteins that are commercially available and that were detected as cleaved by HF3 using LC-MS/MS analysis. The proteins were incubated at a 1:10 (w/w) enzyme-to-substrate ratio with HF3 for $2 \mathrm{~h}$ and subjected to SDSPAGE (Figure 5). Apolipoprotein A-IV was completely degraded by HF3. Apolipoprotein E was almost completely degraded by HF3 to generate a fragment of $\sim 15 \mathrm{kDa}$. After incubation with HF3, clusterin showed a slight reduction of molecular mass, indicating that HF3 may have promoted its limited proteolysis. HF3 also promoted the limited proteolysis of $\alpha$-2-antiplasmin, resulting in fragments of $\sim 68 \mathrm{kDa}$ and $55 \mathrm{kDa}$. The $120 \mathrm{kDa}$ band of high molecular weight kininogen was almost completely degraded by HF3, resulting in a stable fragment of $\sim 68 \mathrm{kDa}$. In the case of transthyretin, its dimer and monomer bands remained unchanged after incubation with HF3. 


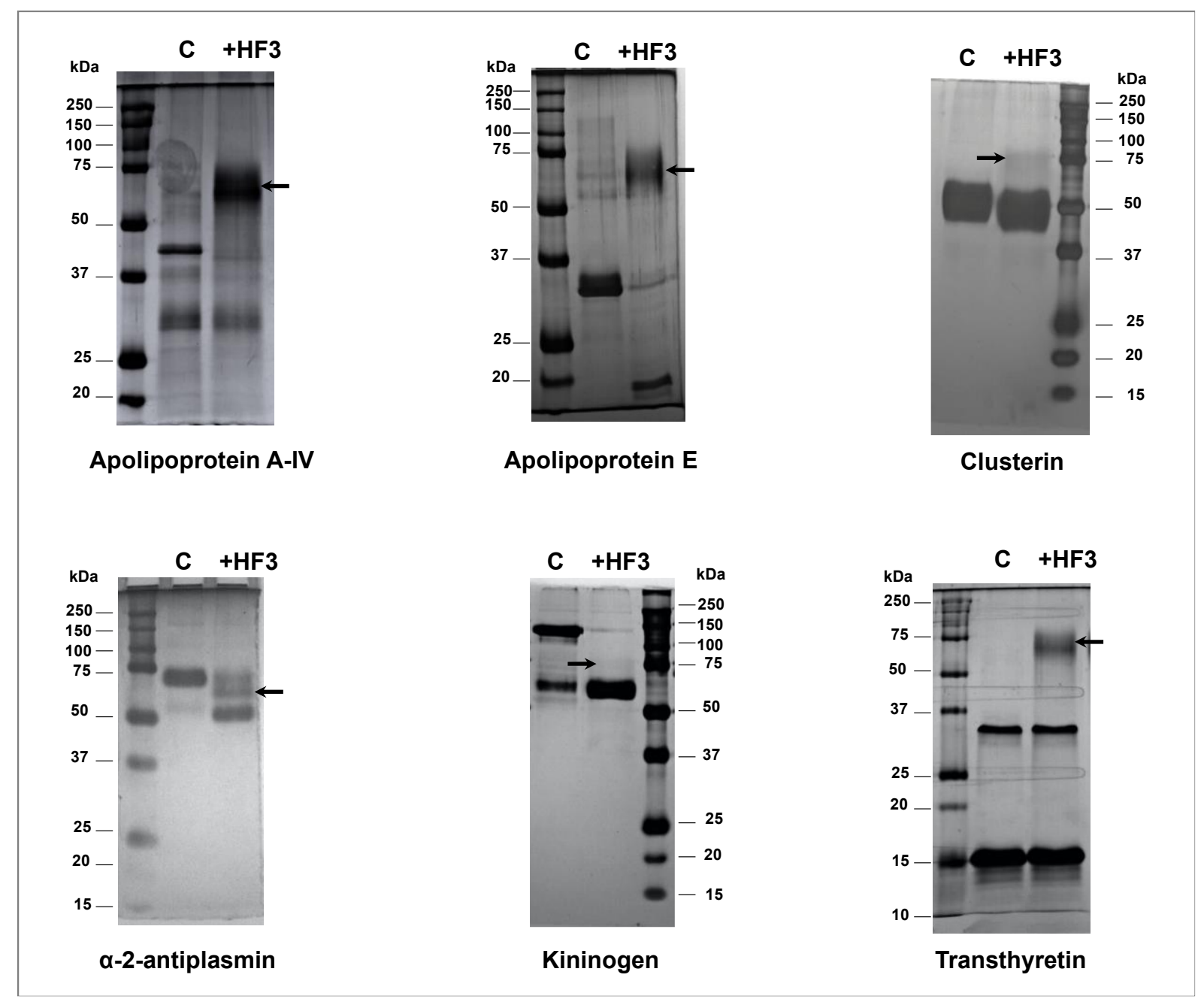

Figure 5. Proteolytic activity of HF3 upon isolated plasma proteins. Apolipoprotein A-IV, apolipoprotein E, clusterin, $\alpha$-2-antiplasmin, kininogen, and transthyretin were incubated at a 1:10 (w/w) enzyme-to-substrate ratio with HF3 for $2 \mathrm{~h}$, as described in Materials and Methods, and subjected to SDS-PAGE. Arrows indicate the band of HF3. Numbers on the right and left indicate molecular mass marker mobility. Proteins were silver stained.

Figure 6 shows the protein-protein interaction network of 61 proteins cleaved by HF3 in the human plasma, visualized using STRING analysis [25], evidencing that most of them (53) have connected molecular functions related mainly to the activation and control of the coagulation and complement systems. 


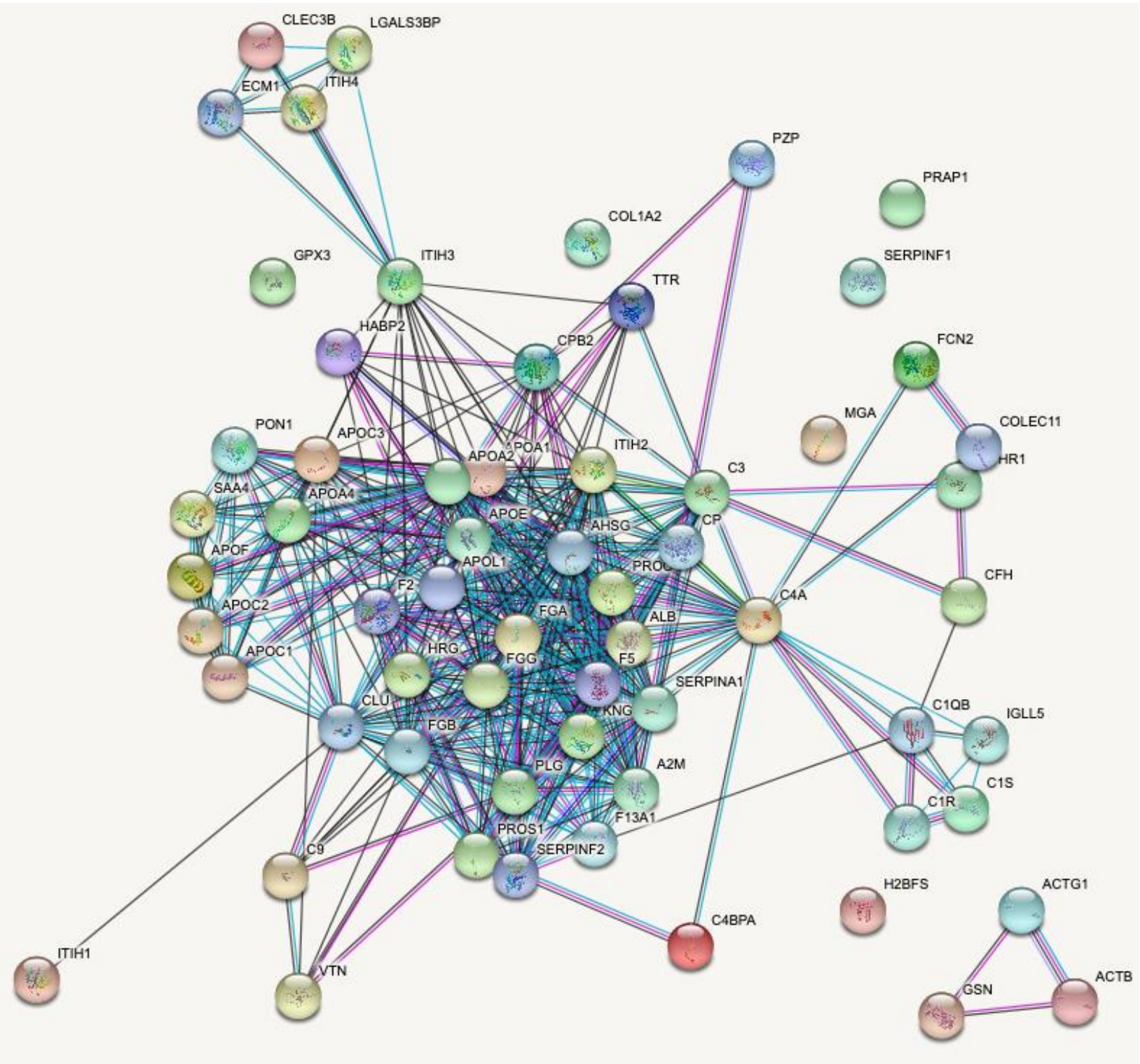

Figure 6. Protein-protein interactions of proteins identified as degraded in human plasma by HF3 according to the STRING database (61 proteins; 401 edges (expected 27); PPI enrichment $p$-value $<1.0^{-16}$ ). The connecting lines between protein nodes indicate protein-protein interactions.

\subsection{Mapping the Primary Specificity of HF3 on Plasma Proteins}

A large number of peptides derived from the activity of HF3 on plasma proteins were identified in the experiments performed with $\mathrm{P}(\mathrm{W}), \mathrm{P}(\mathrm{Alb}-\mathrm{D}), \mathrm{P}(20-\mathrm{MAP}-\mathrm{D})$, and $\mathrm{P}(\mathrm{LAP}-\mathrm{E})$, and these were used for the evaluation of the proteins that were hydrolyzed by HF3, as well as to carry out the mapping of amino acid sequences adjacent to the cleavage sites, which are preferential for the proteinase (primary specificity). For this purpose, we used the amino acid sequences of the peptides, corresponding to the positions $\mathrm{P} 1^{\prime}-\mathrm{P} 6^{\prime}$ [26], identified in the samples treated with HF3, and originating from the proteins considered as substrate, whereas the complementary amino acid sequences (P6-P1) adjacent to the cleavage sites of the respective peptides were obtained using a tool available online at http:/ / clipserve.clip.ubc.ca/pics; accessed on 1 April 2014 [27], which also generated the graphical representation (heat map) of the proteinase cleavage consensus sequence. The heat maps representing the occurrence of amino acids at positions P6-P6' are described in Figure 7, corresponding to the identification results obtained by the Mascot/TPP and 
PEAKS approaches. It was interesting to verify that, although the number of cleavage sites identified by the PEAKS approach was higher than that of Mascot/TPP, the heat maps generated with data from both approaches from data from all plasma samples were very similar and evidenced a clear preference of HF3 for Leu at the P1' position.

The analysis of hydrolysis products of plasma proteins incubated with HF3 showed that fibrinogen was cleaved in the alpha, beta, and gamma chains (Supplementary Material Tables S1-S8). These data corroborate previous studies that described extensive cleavage of the alpha chain, followed by more limited beta chain cleavage [9] by HF3, however, proteolysis of the fibrinogen gamma chain by HF3 was unknown. Here, peptides from the C-terminal region of the fibrinogen gamma chain were identified as a product of HF3 activity in P(20-MAP-D) and P(LAP-E). Studies have shown that the C-terminal region of the fibrinogen gamma chain plays important roles in platelet interaction [28] and fibrin stabilization [29], and that the C-terminal peptide also plays a role in the inhibition of platelet aggregation [30]. Thus, for the validation of peptides generated by cleavage of fibrinogen by HF3 in plasma, it was incubated with isolated fibrinogen, followed by analysis of the resulting peptide fraction by LC-MS/MS. This analysis revealed the peptides generated by the enzymatic activity of HF3, and indirectly, the cleavage points of HF3 in the protein (Supplementary Material Table S9). Figure 8 shows the location of these peptides in the fibrinogen sequence, corresponding to 73 peptides of the alpha chain and 15 peptides of the beta chain. Eight fibrinogen gamma chain peptides were also identified, including two located in the C-terminal region, thus confirming the data obtained by the incubation of HF3 with plasma.

A

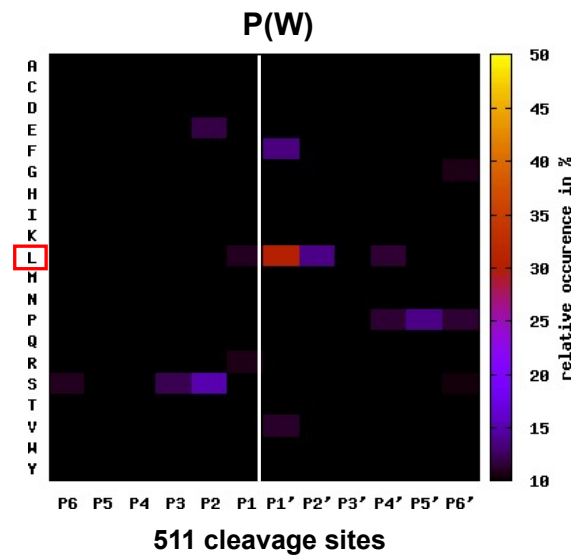

P(20-MAP-D)

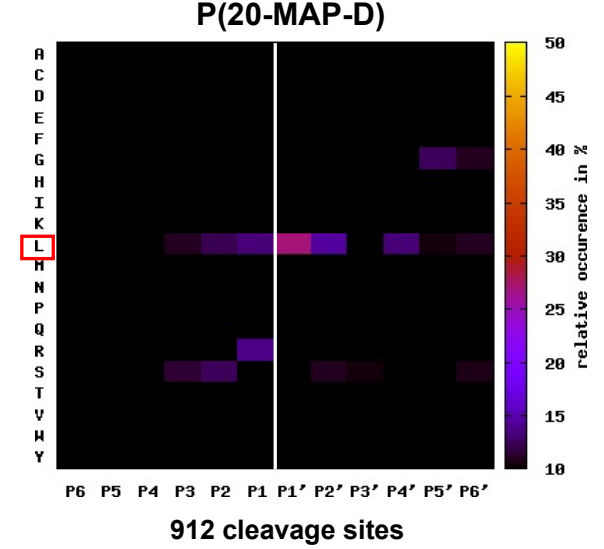

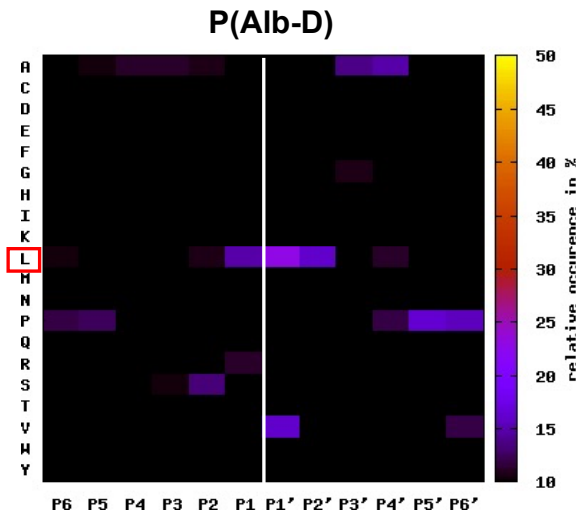

227 cleavage sites

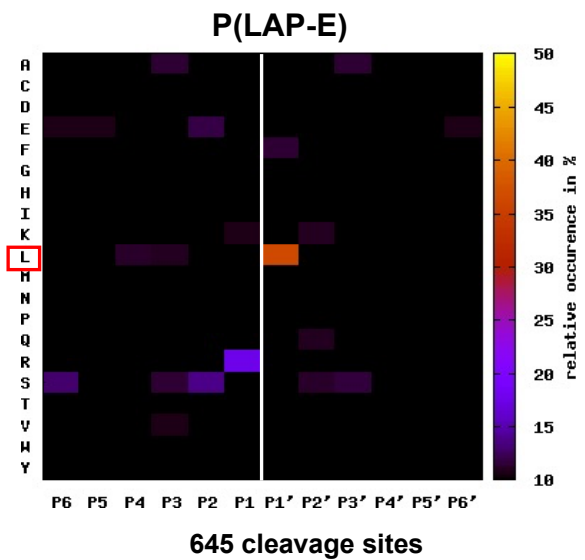

Figure 7. Cont. 


\section{B}
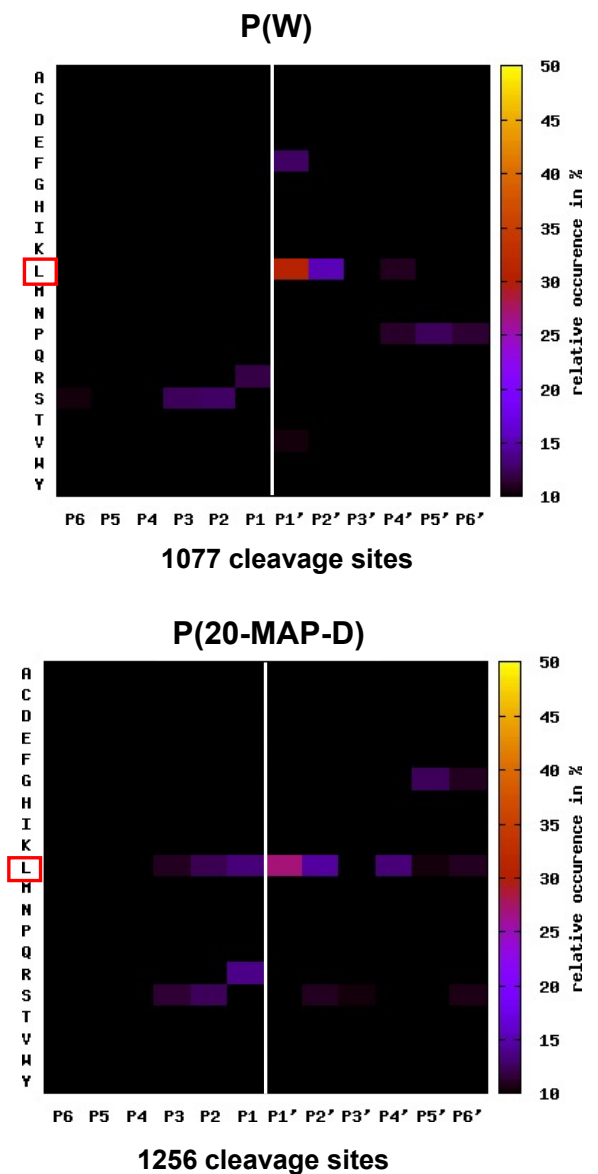
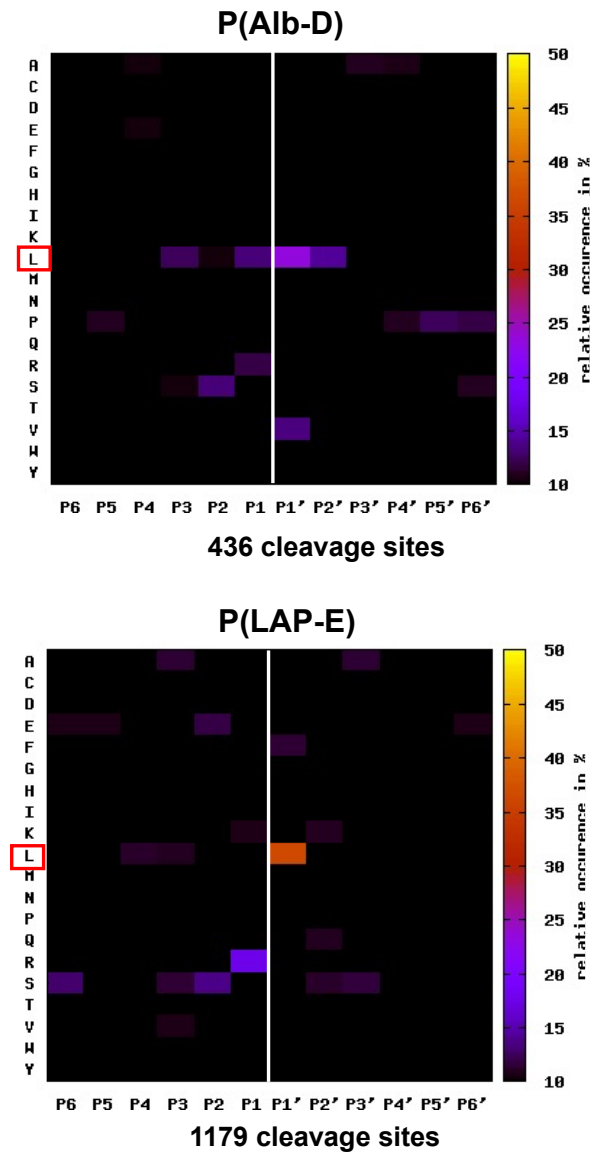

Figure 7. Substrate specificity assessed by the identification of peptides generated by the proteolytic activity of HF3 on human plasma proteins. (A) Heat maps showing the relative occurrence (in \%) of each amino acid residue and the fold-change over the natural abundance of amino acids, identified using Mascot/TPP. (B) Heat maps showing the relative occurrence (in \%) of each amino acid residue and the fold-change over the natural abundance of amino acids, identified using PEAKS. Only peptides derived from proteins identified as HF3 substrates were considered, and peptides identified both in control and treated samples were excluded. Heat maps were created at http:/ / clipserve.clip.ubc.ca/pics (accessed on 1 April 2014). 


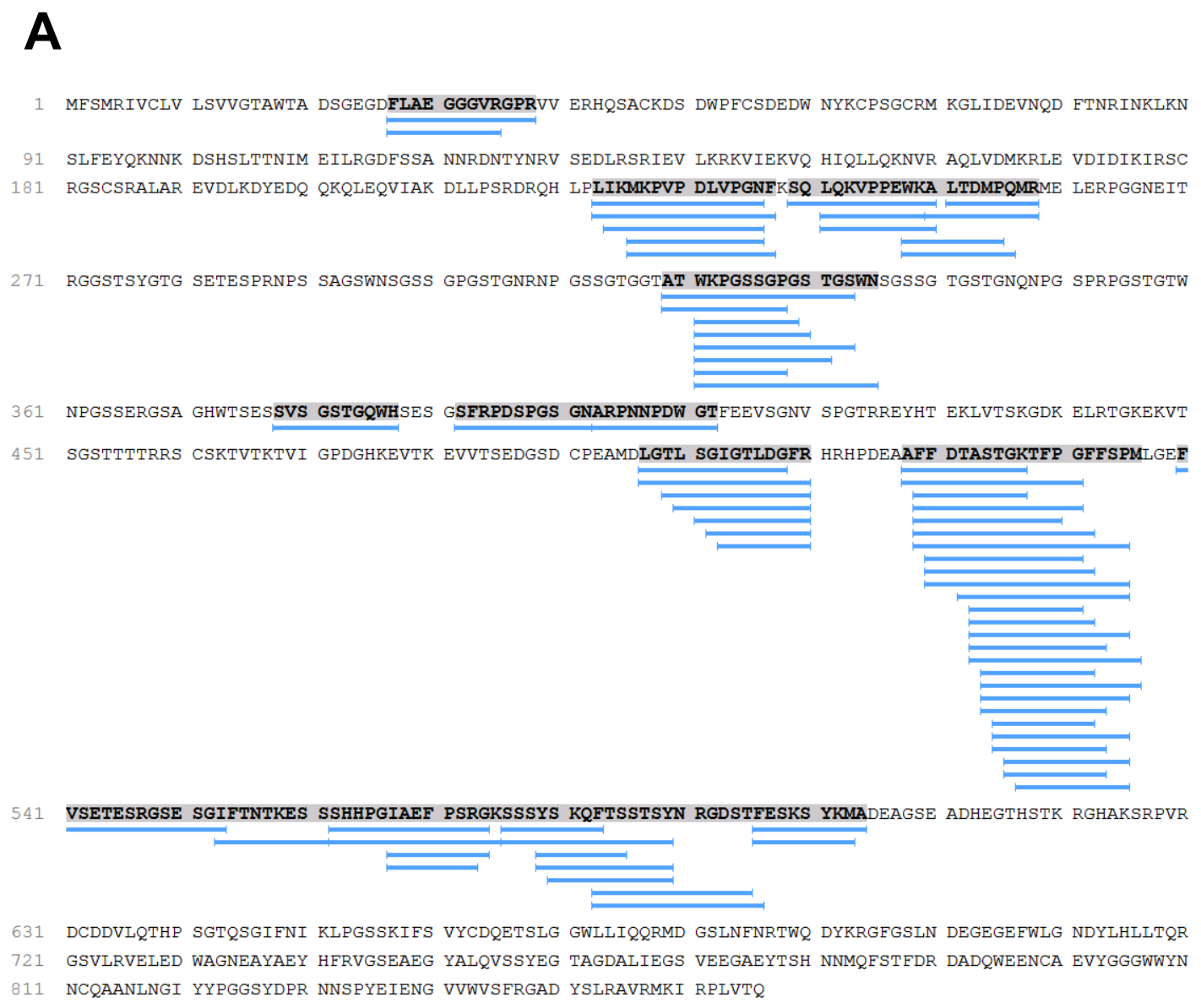

B

1 MKRMVSWSFH KLKTMKHLLL LLLCVFLVKS QGVNDNEEGF FSARGHRPLD KKREEAPSLR PAPPPISGGG YRARPAKAAA TQKKVERKAP

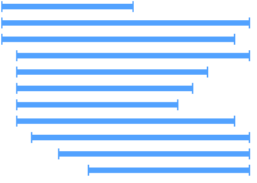

91 DAGGCLHADP DLGVLCPTGC QLQEALLQQE RPIRNSVDEL NNNVEAVSQT SSSSFQYMYL LKDLWQKRQK QVKDNENVVN EYSSELEKHQ

181 LYIDETVNSN IPTNLRVLRS ILENLRSKIQ KLESDVSAQM EYCRTPCTVS CNIPVVSGKE CEEIIRKGGE TSEMYLIQPD SSVKPYRVYC

271 DMNTENGGWT VIQNRQDGSV DFGRKWDPYK QGFGNVATNT DGKNYCGLPG EYWLGNDKIS QLTRMGPTEL LIEMEDWKGD KVKAHYGGFT

361 VQNEANKYQI SVNKYRGTAG NALMDGASQL MGENRTMTIH NGMFFSTYDR DNDGWLTSDP RKQCSKEDGG GWWYNRCHAA NPNGRYYWGG

451 QYTWDMAKHG TDDGVVWMNW KGSWYSMRKM SMKIRPFFPQ \&

C

MSWSLHPRNL ILYFYALLFL SSTCVAYVAT RDNCCILDER FGSYCPTTCG IADFLSTYQT KVDKDLQSLE DILHQVENKT SEVKQLIKAI

QLTYNPDESS KPNMIDAATL KSRKMLEEIM KYEASILTHD SSIRYLQEIY NSNNQKIVNL KEKVAQLEAQ CQEPCKDTVQ IHDITGKDCQ

181 DIANKGAKQS GLYFIKPLKA NQQFLVYCEI DGSGNGWTVF QKRLDGSVDF KKNWIQYKEG FGHLSPTGTT EFWLGNEKIH LISTQSAIPY

271 ALRVELEDWN GRTSTADYAM FKVGPEADKY RLTYAYFAGG DAGDAFDGFD FGDDPSDKFF TSHNGMQFST WDNDNDKFEG NCAEQDGSGW

361 WMNKCHAGHL NGVYYQGGTY SKASTPNGYD NGIIWATWKT RWYSMKKTTM KIIPFNRLTI GEGQQHHLGG AKQAGDV

Figure 8. Amino acid sequence of human fibrinogen alpha (A), beta (B), and gamma (C) chains, indicating the identified cleavage products (blue bars) generated by the incubation with HF3. Graphical view generated with PEAKS Studio 7. 


\section{Discussion}

\subsection{Human Plasma Preparations for Degradomic Analysis}

The application of methods for the depletion of the most abundant proteins in human plasma, and for the enrichment of low-abundant proteins, resulted in samples with significantly different electrophoretic profiles, which allowed us to evaluate the proteolytic activity of HF3 on a wide spectrum of proteins in concentrations that allowed the detection of degradation products by mass spectrometry. Regarding the electrophoretic profile, P(LAP-E) showed the clearest differences in comparison to whole plasma, a fact that can be directly attributed to the principle of the ProteoMiner technology, which, by equalizing the proteome of a sample, significantly alters the concentration of proteins poorly represented in a proteome. Millioni et al., 2011, compared techniques for depleting the 20 most abundant proteins with the ProteoPrep 20 column and the enrichment of less abundant proteins with ProteoMiner, for the analysis of the plasma proteome [31]. They reported that the methods were complementary regarding the identified proteins, however, a higher number of proteins was identified in the plasma proteome depleted of the 20 most abundant proteins. Hakimi et al., 2014, tested the efficacy and reproducibility of these methods for plasma protein depletion/enrichment, and by comparing 18 randomly chosen proteins, they found that both techniques were reproducible [32]. However, the protein enrichment approach with ProteoMiner provided a greater number of identified proteins. It is worth emphasizing that a large part of the studies that employ techniques for the depletion of the most abundant proteins in the plasma or enrichment of low-abundant proteins aim to characterize the plasma proteome itself, and more often, the search for biomarkers [33-37]. Studies aimed at analyzing the repertoire of substrates of a proteinase on a given proteome are less frequent, and generally employ methods for the depletion of abundant proteins after the action of the proteinase, in a step prior to one-dimensional or two-dimensional electrophoresis [18,19,38], or do not employ protein depletion/enrichment techniques [39-41]. In the present study, plasma protein depletion/enrichment techniques were used in a step prior to incubation with the proteinase. Thus, it was possible to evaluate the proteolytic activity of HF3 through the identification of peptides from the cleaved proteins, for the characterization of the HF3 degradome in the human plasma in vitro.

\subsection{Analysis of the Plasma Peptide Fraction}

Considering that the peptides identified by mass spectrometry after the incubation of plasma with HF3, which were absent in their respective control, are probably products arising from the cleavage of plasma proteins by HF3, the structure of these peptides indicates the substrates degraded by this proteinase. To elucidate the HF3 cleavage products by the analysis of the peptide fraction, we used two bioinformatics approaches with restrictive criteria for peptide identification. In addition, to be considered as HF3 substrate, proteins whose peptides were identified in the peptide fraction were again subjected to restrictive criteria for comparing samples treated with HF3 and control: (i) the peptides identified in the control samples were subtracted from the list of peptides identified in the HF3-treated samples, as they were potentially not generated by HF3, thus, only peptides identified exclusively in the treated sample remained in the analysis; (ii) proteins were considered cleaved by HF3 if their peptides (hydrolysis products) were present in at least two of the three experiments performed. In view of these criteria, we identified that 70 protein entries present in the UniProt database (considering individual oligomeric protein chains as different entries) were identified as HF3 substrates, and of these, 61 are unique proteins. Some of these proteins corroborate data described in the literature and others are considered new substrates of this metalloproteinase.

In general, for each method of preparation of human plasma, a large portion of the proteins considered as a target of HF3 were identified by both bioinformatics approaches used. The PEAKS approach provided a greater number of proteins identified in $\mathrm{P}(W)$, $\mathrm{P}(20-\mathrm{MAP}-\mathrm{D})$, and P(LAP-E), whereas the Mascot/TPP approach provided a greater number of proteins identified as substrate in the P(Alb-D) approach. Zhang et al., 2012, com- 
pared, for data from LC-MS/MS analysis of trypsin digestion of Pseudomonas aeruginosa, the number of peptide-to-spectrum match (PSM) identified by PEAKS and Mascot, using a database search [42]. The study showed that PEAKS provided 30\% more PSMs when compared to Mascot. In the present study, higher numbers of spectral counts and identified peptides were detected in the analysis of the peptide fraction of the plasma incubated with HF3 by PEAKS, nevertheless, most substrates were identified by both bioinformatics approaches.

The direct incubation of some of the new substrate candidates with HF3 and the visualization of cleavage products by SDS-PAGE confirmed its proteolytic activity upon human plasma proteins, as detected by LC-MS/MS analysis. Furthermore, it revealed different outcomes, i.e., limited proteolysis or degradation, resulting from the hydrolysis of plasma proteins by HF3. In the case of transthyretin, however, as most peptides identified as cleavage products derived from the incubation of HF3 with plasma were derived from its $\mathrm{N}$ - and C-terminal regions, its direct incubation with HF3 did not show any change in the bands corresponding to its dimer and monomer forms, as visualized by SDS-PAGE.

\subsection{Analysis of the Primary Specificity of HF3 on Plasma Proteins}

The use of peptides generated by the cleavage of plasma proteins by HF3 proved to be an excellent tool to evaluate its primary specificity, since a large number of cleavage sites were analyzed (2295 identified by Mascot/TPP and 3948 by PEAKS) and showed the preference of HF3 for Leu in the P1' position. In agreement with these results, the analysis of the primary specificity of HF3, using data resulting from cleavage events in native proteins present in the secretome of a mouse embryonic fibroblast analyzed by TAILS technology, showed a predominance of Leu at $\mathrm{P} 1^{\prime}$ position [20]. Interestingly, the analysis of the activity of HF3 on human plasma peptide substrates by the PICS approach showed a similar pattern, in which Leu had a higher occurrence at $\mathrm{P}^{\prime}$ position, followed by hydrophobic residues in $\mathrm{P}^{\prime}$ [21]. The preference for Leu at the $\mathrm{P} 1^{\prime}$ subsite is a common feature of metalloproteinases, such as matrix metalloproteases (MMPs) [43]. In the study by Kleifeld et al., 2010, the primary specificity of matrix metalloproteinase 2 (MMP-2) was evaluated by the TAILS method, showing a strong preference for Leu at the $\mathrm{P} 1^{\prime}$ position (more than $45 \%$ occurrence) and Pro at the P3 position [44]. Using the same approach, Prudova et al., 2010, found that MMP-2 had a strong preference for Leu in position P1 ${ }^{\prime}$ and Pro in P3, whereas MMP-9 exhibited a more relaxed preference for Leu in P1' and a very strong preference for Pro in P3, reflecting the differences in the S1'subsites of these proteinases [45]. MMP-10 also revealed its preference for Leu at the $\mathrm{P} 1^{\prime}$ position and Pro at the P3 position [46]. Unlike what has been shown in these studies, the results of the analysis on the primary specificity of HF3 on plasma proteins did not indicate a significant preference for any amino acid at positions other than $\mathrm{P}^{\prime}$, indicating that amino acids present at positions adjacent to the cleavage site do not have a relevant role in determining the hydrolysis of peptide bonds in proteins by HF3.

\subsection{Plasma Proteins Cleaved by HF3}

Fibrinogen peptides (alpha and beta chains), vitronectin, and fibronectin were considered as cleaved by HF3, corroborating previous studies by our group that showed that these proteins are hydrolyzed by HF3 in vitro [9]. The results obtained in the present study also confirm data from Paes Leme et al., 2012 [19], who showed that fibronectin and fibrinogen were degraded in the plasma of mice injected in the dorsal skin with HF3. Although fibrinogen alpha and beta chains have already been described as HF3 substrates, in this study, the fibrinogen gamma chain was also detected as a target of this metalloproteinase. Peptides from the fibrinogen gamma chain were identified as a product of HF3 activity on P(20-MAP-D) and P(LAP-E). In addition, incubation of HF3 with isolated fibrinogen, followed by analysis of the resulting peptide fraction by LC-MS/MS, confirmed the presence of these peptides. These analyses revealed the release of peptides from the C-terminal portion of the fibrinogen gamma chain by HF3. In addition to the important role of this region in the stabilization of fibrin by cross-linking [29], studies have shown 
that the C-terminal region of the gamma chain is involved in its interaction with the $\alpha \operatorname{Ilb} \beta 3$ integrin in platelets [28,47,48]. Farrell et al., 1992, also found that a recombinant fibrinogen, which contained an interruption in the C-terminal region of the gamma chain, lost much of its ability to mediate platelet aggregation [49]. In addition, the C-terminal gamma-chain fibrinogen peptide (HHLGGAKQAGDV) demonstrated the ability to inhibit platelet aggregation and fibrinogen binding to rabbit platelets, through its direct interaction with GPIIb-IIIa [30]. Thus, it is possible that the cleavage of the fibrinogen gamma chain by HF3, detected upon incubation with plasma or isolated fibrinogen, results in the release of the C-terminal peptide, potentially affecting platelet aggregation.

In the same work by Paes Leme et al., 2012, alpha-1-antitrypsin, a serine proteinase inhibitor, was found in lower concentration in the skin injected with HF3 in comparison with the control skin. In the present study, we found that HF3 was able to cleave this protein in vitro, in agreement with its lower abundance in the skin of mice treated with HF3 [19]. Alpha-1-antitrypsin has anti-apoptotic effects and can act as a negative inflammatory regulator [50], thus, considering that HF3 and other metalloproteinases from venoms have pro-inflammatory activity, the degradation of alpha-1-antitrypsin could facilitate the development of inflammation. Peptides derived from alpha-2-macroglobulin and transthyretin were detected in the peptide fraction of plasma treated with HF3, indicating their proteolysis. These proteins were, however, found in higher abundance in the skin of mice injected with HF3, according to Paes Leme et al., 2012 [19], probably due to the increase of blood in the hemorrhagic skin. However, in agreement with the present study, we showed that alpha-2-macroglobulin was not able to inactivate the proteolytic activity of HF3 in vitro, and instead, was partially hydrolyzed by HF3 [16].

Plasminogen, a component of the fibrinolytic system, was identified as a substrate for HF3, but its limited cleavage was only detected in P(LAP-E), with a low number of identified peptides. Plasminogen is a single-chain glycoprotein that circulates in plasma in zymogen form and, when activated by urokinase (u-PA) or tissue plasminogen activator (t-PA) by cleavage of the Arg580-Val581 bond, it is converted to plasmin, and thus is able to cleave fibrin [51]. Angiostatin is an antiangiogenic protein that has been identified as the primary factor controlling the dormant state of cells in a secondary metastatic tumor, inhibiting angiogenesis and resulting in decreased blood flow and reduction in tumor size [52]. Angiostatin is a $38 \mathrm{kDa}$ internal fragment of plasminogen [53], and angiostatinlike molecules can be generated in a variety of ways, including processing of plasminogen by various matrix metalloproteinases [54]. Ho et al., 2002, showed that metalloproteinases from Bothrops venoms, when incubated with plasminogen, were capable of generating a product of $38 \mathrm{kDa}$, and whose $\mathrm{N}$-terminal sequencing evidenced the cleavage in the Ser460-Val461 bond, indicating the generation of an angiostatin-like protein [55]. Here, peptides identified in the peptide fraction of plasma treated with HF3 indicated cleavages in plasminogen close to the regions of initiation and termination of angiostatin. Furthermore, in a recent study, the incubation of HF3 with the isolated plasminogen did generate a product with a molecular mass close to $38 \mathrm{kDa}$ [15], indicating that the limited proteolysis of plasminogen by HF3 indeed generates a protein similar to angiostatin. As angiostatin modulates the rate of plasminogen activation through non-competitive inhibition of the tissue-type plasminogen activator, the cleavage of plasminogen by HF3 and the generation of angiostatin would result in the decrease of the concentration of plasminogen in plasma, and as a consequence, its activity in the fibrinolytic system would be compromised. The impairment in the generation of plasmin, through the decrease of the concentration of plasminogen, would significantly affect the negative feedback of the coagulation cascade and, in turn, would also contribute to the fibrinogen consumption during the coagulopathies triggered by snake envenomation.

Prothrombin (coagulation factor II) was found in higher abundance in the plasma of mice injected with HF3 in the dorsal skin, in comparison to the plasma of mice treated with the control solution [19], by the analysis of plasma proteins subjected to in solution digestion with trypsin, and spectra count by LC-MS/MS. In the present study, prothrombin 
was identified as cleaved by HF3 by analyzing the plasma peptide fraction. The cleavage of prothrombin has also been shown by incubating the isolated protein with HF3, followed by SDS-PAGE, which revealed products of $\sim 28,30,35$, and $50 \mathrm{kDa}$ [15]. The presence of many peptides from prothrombin in the peptide fraction of plasma treated with HF3 indicates that this protein is rather degraded and not activated by the proteinase, and as a consequence, prothrombin would be unavailable to participate in the blood coagulation process, where it is activated by factor $\mathrm{Xa}$ and converted into thrombin. The increase in prothrombin in the plasma of mice injected with HF3, verified in the study by Paes Leme et al., 2012 [19], could be explained as an attempt by the organism (mouse) to counteract, not only the hemorrhagic process, but also the cleavage of the protein itself by HF3, providing more protein to the coagulation cascade.

Alpha-2-antiplasmin is a serine proteinase inhibitor (serpin) that acts to protect fibrin clots from plasmin-mediated cleavage [56]. The plasmin inhibition by the serpin occurs primarily by the binding of the Gln 41 residue from its N-terminal region to the Lys 342 residue of the fibrin alpha chain, mediated by factor XIIIa. Then, the C-terminal domain of alpha-2-antiplasmin interacts with plasmin, so that its Arg403 aligns and forms a covalent bond with the Ser residue present in the active site of plasmin, forming an inactive enzymeinhibitor complex [57]. Alpha-2-antiplasmin can be found in plasma either in its mature form (452 amino acids) or in its propeptide-containing form (464 amino acids) [58]. Proalpha-2-antiplasmin has inhibitory activity on plasmin, however, its ability to cross-link fibrin is reduced by approximately one third compared to the mature protein [59]. The peptide products generated from alpha-2-antiplasmin by HF3 indicated that both the mature protein and pro-protein forms were cleaved. However, no peptide corresponding to the exact sequence of the pro-domain was identified (M-E-P-L-G-R-Q-L-T-S-G-P), indicating that HF3 would not be able to activate the pro-protein. Furthermore, we detected that HF3 was able to cleave peptides from the $\mathrm{N}$-terminal region of alpha-2-antiplasmin, containing the Gln41 residue involved in the crosslinking to fibrin. Moreover, the C-terminal region was also degraded by the HF3, but the sequence containing the Arg403 residue did not undergo hydrolysis. In view of these findings, we can suggest that HF3 would prevent the binding of alpha-2-antiplasmin to fibrin, however, the effect of HF3 on its inhibitory activity needs further investigation.

In addition to prothrombin, coagulation factor XIII was identified as a substrate of HF3. However, only two peptides ( ${ }^{29}$ TVELQGVVPR ${ }^{38}$ and ${ }^{464}{ }^{\text {LIVTKQIGGDGMMDITDT }}{ }^{481}$ ) were identified as generated by HF3 from factor XIII (chain A) in P(20-MAP-D), indicating limited proteolysis. The analysis of the activity of HF3 upon isolated factor XIII by SDSPAGE revealed only a weak protein band of $\sim 28 \mathrm{kDa}$, which could correspond to the region corresponding to residues $482-732$ of the A chain of Factor XIII [15]. Factor XIII is a transglutaminase that circulates in the human plasma as a heterotetramer of two A and two B chains [60]. Activated Factor XIII (FXIIIa) is responsible for stabilizing fibrin by introducing covalent cross-links [61]. FXIIIa is also responsible for cross-linking alpha2-antiplasmin and fibrin. The activation of FXIII is catalyzed by thrombin that cleaves the Arg38-Gly39 bonds of the A chain of the A2B2 tetramer, leading to chain dissociation and exposure of the cysteine residue of the catalytic site [62]. The identification of the peptide ${ }^{29}$ TVELQGVVPR $^{38}$, which contains the thrombin cleavage site, is an indication of a possible activation of Factor XIII by HF3, however, as other FXIII A chain peptides were identified, it is not possible to state whether the effect of HF3 on this protein is degradation or activation.

Kininogen was identified as a substrate for HF3 in all plasma samples used in this study, and by both bioinformatics methods for protein identification. Peptides derived from both high molecular weight and low molecular weight kininogens have been identified and their extensive proteolysis has been indicated. High molecular weight kininogen participates in the coagulation cascade and the kallikrein-kinin system, whereas low molecular weight kininogen participates only in the latter [63]. These proteins are identical throughout their heavy chains, in the region containing bradykinin, and in the twelve amino acids 
in the N-terminal region of their light chains. Their heavy chains confer them the function of cysteine proteinase inhibitors [64]. The peptides bradykinin or lysyl-bradykinin are released from both kininogen forms when cleaved by kallikreins. In addition to its vasodilatory function, bradykinin (R-P-P-G-F-S-P-F-R) is an inflammation-mediating peptide [65]. The clotting activity of high molecular weight kininogen resides in its light chain [66], the region through which it binds to prekallikrein and factor XI. Furthermore, the same light chain contains a region rich in histidine, responsible for its binding to negatively charged surfaces [67]. The peptides identified as hydrolysis products generated by HF3 are located in the heavy chain of both kininogens, which would compromise their cysteine proteinase inhibitor function. In addition, the light chain of the high molecular weight kininogen was also cleaved by HF3, which would compromise its role in the coagulation cascade. Finally, we found that the region containing the peptide corresponding to bradykinin is cleaved by HF3, but no peptide corresponding to the exact bradykinin sequence was identified, so further investigations are needed to evaluate whether proteolysis of this region would have any effect on the kallikrein-kinin system.

Ceruloplasmin was also identified as a substrate for HF3, although a low number of peptides was detected as a hydrolysis product, and only in the peptide fraction of $\mathrm{P}(\mathrm{Alb}-\mathrm{D})$ after treatment with HF3. This protein has a high degree of homology with the factor V (A chain) of the coagulation cascade [68]. Ceruloplasmin carries more than $95 \%$ of the copper present in plasma, and its function is related to the regulation of copper and iron homeostasis, in addition to its role in angiogenesis and antioxidant activity [69]. Ceruloplasmin is also an acute phase protein and its plasma level increases in response to inflammation [70,71]. Walker and Fay (1990) reported its ability to bind to protein C, thus protecting factors Va and VIII from inactivation catalyzed by activated protein C. Thus, its hydrolysis by HF3 could be involved in the hemorrhagic process [72].

The complement system, which is part of the innate immune system, is composed of more than 30 plasma proteins and cell surface receptors that react with each other in a range of functions, including direct cell lysis and enhancement of $B$ and $T$ cell responses, and induce a series of inflammatory responses that contribute to fighting infection [73-75]. Some proteins are proteinases that are activated in a proteolytic cleavage cascade, similar to the blood coagulation cascade [76]. The activation of the complement system by snake venom components and its role in the envenomation has been shown with venoms from the Elapidae and Viperidae families [77,78]. Among other potential new targets for HF3, this study identified some components of the complement cascade: $\mathrm{C} 1 \mathrm{r} ; \mathrm{C} 1 \mathrm{~s} ; \mathrm{C} 3 ; \mathrm{C} 4$ and C9; $\mathrm{C} 4 \mathrm{~b}$ binding protein (alpha chain); complement factor $\mathrm{H}$; and factor $\mathrm{H}$-related protein 1. Cleavage of components $\mathrm{C} 3$ and $\mathrm{C} 4$ was confirmed by incubation of HF3 with these isolated proteins [15], indicating that they would not be available in plasma to participate in the complement cascade activation process, hence HF3 would play a role as a modulator of this cascade of proteinases.

Peptides from clusterin (apoliprotein J) were identified in the peptide fraction of $\mathrm{P}(\mathrm{W})$, $\mathrm{P}(\mathrm{Alb}-\mathrm{D}), \mathrm{P}(20-\mathrm{MAP}-\mathrm{D})$, and $\mathrm{P}(\mathrm{LAP}-\mathrm{E})$ after incubation with HF3, indicating an extensive degradation of this protein. Clusterin is a chaperone protein with anti-inflammatory and cytoprotective activity, which inhibits MMP-9, MMP-2, MMP-3, and MMP-7 [79], so its proteolysis by HF3 could prevent its anti-inflammatory activity. Further, it is possible to suggest that, opposite to what happens with MMPs, clusterin would not be an inhibitor of HF3.

The results of the present study also showed potential new HF3 targets, such as alpha-2-HS-glycoprotein, or fetuin-A, which was shown as extensively degraded by HF3. This protein functions as an important component of several physiological or pathological mechanisms, including vascular calcification, bone metabolism, insulin resistance, keratinocyte migration, and breast cancer tumor cell proliferative signaling [80]. In response to acute inflammation, alpha-2-HS-glycoprotein appears to act as an anti-inflammatory modulator. Alpha-2-HS-glycoprotein has been shown to suppress the excessive release of tumor necrosis factor from activated macrophages [80-82]. Hence, the proteolysis of alpha-2-HS-glycoprotein by HF3 would impair its anti-inflammatory activity. Meprins 
are zinc-dependent, astacin-like metalloproteinases that play a pivotal role in inflammation by activating cytokines, and the potential role of endogenous meprin inhibitor has also been attributed to alpha-2-HS-glycoprotein [80,83,84]. Guerranti et al., 2010 [38], reported the proteolysis of alpha-2-HS-glycoprotein after incubation of human plasma with Echis carinatus venom, however, the component of the venom responsible for its degradation has not been investigated. To our knowledge, there are no reports on the cleavage of alpha-2-HS-glycoprotein by other venom metalloproteinases, and its degradation by HF3 would potentially have a pro-inflammatory effect.

In the study by Paes Leme et al., 2012 [19], it was found that apolipoprotein A-II, the second major component of HDL particles, was clearly degraded in the hemorrhagic process generated by HF3. Here we show that not only apolipoprotein A-II, but also other proteins of the same family (apolipoprotein AI, A-IV, CI, C-II, C-III, E, F, and L1), were detected as substrates of HF3. Apolipoproteins bind and transport lipids, and members of classes A, C, and E play an important role in lipoprotein metabolism and in inflammatory processes [85]. Previous studies have shown that apolipoproteins AI and E are cleaved by matrix metalloproteinase 14 (MMP-14) [39], whereas apolipoproteins C-II and A-IV are cleaved by matrix metalloproteinases 7 and 14 [86-88]. The cleavage of apolipoproteins A-I and A-II by metalloproteinases from the venom of Cerastes cerastes was observed by El-Asmar and Swaney (1988) [89], and the cleavage of apolipoprotein A-I by proteinases in the venom of Echis carinatus was also reported by Guerranti et al., 2010 [38]. However, the role of proteolysis of these apolipoproteins in the context of envenomation is not well established, and a hypothesis that can be suggested is that the degradation products of these proteins could play a role in modulating the pro-inflammatory activity of venom metalloproteinases. Whether this modulation would be characterized by the increase or by the limitation of the pro-inflammatory effects is a matter of future investigation.

Gelsolin was identified as a substrate for HF3 in P(W), P(20-MAP-D), and P(LAP-E), and was extensively degraded. In another study by our group on the degradation of proteins secreted by fibroblasts, the cleavage of gelsolin by HF3 was also identified by the TAILS approach [20]. Plasma gelsolin, together with the vitamin D-binding protein, forms part of the actin scavenger system [90,91]. Excessive release of intracellular actin or decreased activity of the scavenger system is associated with pathological conditions such as small blood vessel obstruction, clots, endothelial damage, hepatic necrosis, and septic shock [92]. Studies using degradomics approaches showed that gelsolin is a substrate of matrix metalloproteinases, and MMP-3 is able to cleave it more efficiently, followed by MMP-2, MMP-1, and MMP-14 [93]. Thus, as in the case of MMPs, gelsolin cleavage by HF3 could affect the actin scavenging system and promote pathological conditions induced by an excess of unremoved extracellular actin.

Many peptides from the $\mathrm{H} 1, \mathrm{H} 2, \mathrm{H} 3$, and $\mathrm{H} 4$ heavy chains of inter-alpha trypsin inhibitor family proteins were identified in the peptide fraction of plasma after incubation with HF3, indicating extensive cleavage of these polypeptide chains. Proteins of the interalpha trypsin inhibitor family are composed of a common light chain (the chondroitin sulfate proteoglycan bikunin), and various heavy chains [94,95]. Bikunin shows inhibitory activity on a wide spectrum of proteinases, including some of pathological importance, such as trypsin, chymotrypsin, plasmin, elastase, and cathepsin. Bikunin is also recognized as an anti-inflammatory mediator [96]. The binding of the heavy chains of the interalpha trypsin inhibitor to hyaluronan may be involved in the stabilization and integrity of the extracellular matrix, and provides anti-inflammatory properties [97-99]. Catanese and Kress (1985) reported on the in vitro cleavage of the inter-alpha trypsin inhibitor by metalloproteinases from viperid, colubrid, and elapid venoms, generating products still capable of inhibiting trypsin [100]. The degradation of $\mathrm{H} 1-\mathrm{H} 4$ chains of inter-alpha trypsin inhibitor by HF3 would likely not impair the ability of its light chain to inhibit serine proteinases, but would affect its anti-inflammatory activity. 
The histidine-rich glycoprotein was also identified as cleaved by HF3, however, this cleavage was very specific and generated peptides within the sequence HSHGPPLPQGPPPLLPM of its proline-rich region [101]. Histidine-rich glycoprotein is found in plasma, leukocytes, platelet $\alpha$-granules, and megakaryocytes. It contains various binding domains, and interacts with the heme group, plasminogen, heparin, fibrinogen, thrombospondin, immunoglobulin $\mathrm{G}$, complement components, and $\mathrm{Zn}^{2+}$ ions [102]. Histidine-rich glycoprotein can also interact with cell-associated molecules, including Fc $\gamma$ receptors, heparan sulfate, and phospholipids [102]. In the context of this study, the most interesting aspect of the histidine-rich glycoprotein lies in its ability to modulate components of the coagulation cascade. It can bind to heparin released by mast cells, preventing it from inhibiting the procoagulant activity of monocytes at the site of inflammation and thrombosis [101,103]. Some studies have demonstrated the profibrinolytic effect of histidine-rich glycoprotein, by its ability to bind to plasminogen, stimulating its cleavage by plasmin [104]. Other studies, on the other hand, have investigated its action as an antifibrinolytic agent, as the histidine-rich glycoprotein binding to plasminogen could interfere with the interaction of plasminogen with fibrin clots, thus inhibiting plasmin-mediated fibrinolysis [101,105]. Thus, the cleavage of histidine-rich glycoprotein by HF3 would have a variety of implications in the context of hemorrhage, mostly related to its role in regulating hemostasis.

Other proteins were detected as cleaved by HF3, but a low number of peptides were found as hydrolysis products, and mostly in only one type of plasma preparation: carboxypeptidase B2; collectin-11; ficolin-2; galectin-3 binding protein; glutathione peroxidase 3; histone H2B type FS; hyaluronan binding protein; MAX gene-associated protein isoform 3; pigmented epithelial-derived factor; pregnancy zone protein; proline-rich acidic proteins; amyloid A protein -4 serum; immunoglobulins; tetranectin; and serum paraoxonase/arylesterase. These proteins do not have a defined role in the generation of hemorrhage, and thus the implications of their hydrolysis by HF3 need further investigation.

\section{Conclusions}

The human plasma depletion methods used in this study provided heterogeneous samples with respect to the range of dynamic protein concentration, which were compatible with the peptidomic analysis, and generated complementary results for the elucidation of the HF3 degradome. The two bioinformatics approaches used for the analysis of the peptide fraction gave robustness to the set of obtained results, since most proteins identified as HF3 substrates were detected by both. The determination of the primary specificity of HF3 on protein substrates showed that Leu at $\mathrm{P}^{\prime}$ is a major determinant of HF3 primary specificity, which agrees with previous studies using peptides, and reinforces the importance of this residue at $\mathrm{P} 1^{\prime}$, regardless of the substrate structure.

As a result of this study, knowledge about the HF3 substrate repertoire in human plasma has been expanded in terms of number, as well as protein classes and functions (Figure 9). Taken together, the results illustrate the proteolytic signature of human plasma in the context of HF3-induced hemorrhage. By acting on distinct substrates, which are part of a highly connected biological circuit, the proteolytic signaling triggered by HF3 may not be fully anticipated by the results of in vitro incubation with single substrates. Actually, the activated/impaired biological pathways involved in the hemorrhagic and pro-inflammatory effects of SVMPs are the result of complex signaling circuits, which are significantly affected by limited proteolysis and protein degradation. In this regard, it was interesting to note that the hydrolysis of some proteins by HF3 seems to lead to antagonistic results, such as the hydrolysis of fibrinogen and plasminogen, which play roles in different steps of blood coagulation and fibrinolysis. In general, the characterization of HF3 substrate degradome in the human plasma suggests that it acts in a dysregulated manner, refractory to plasma inhibitors, causing an imbalance in hemostasis. 


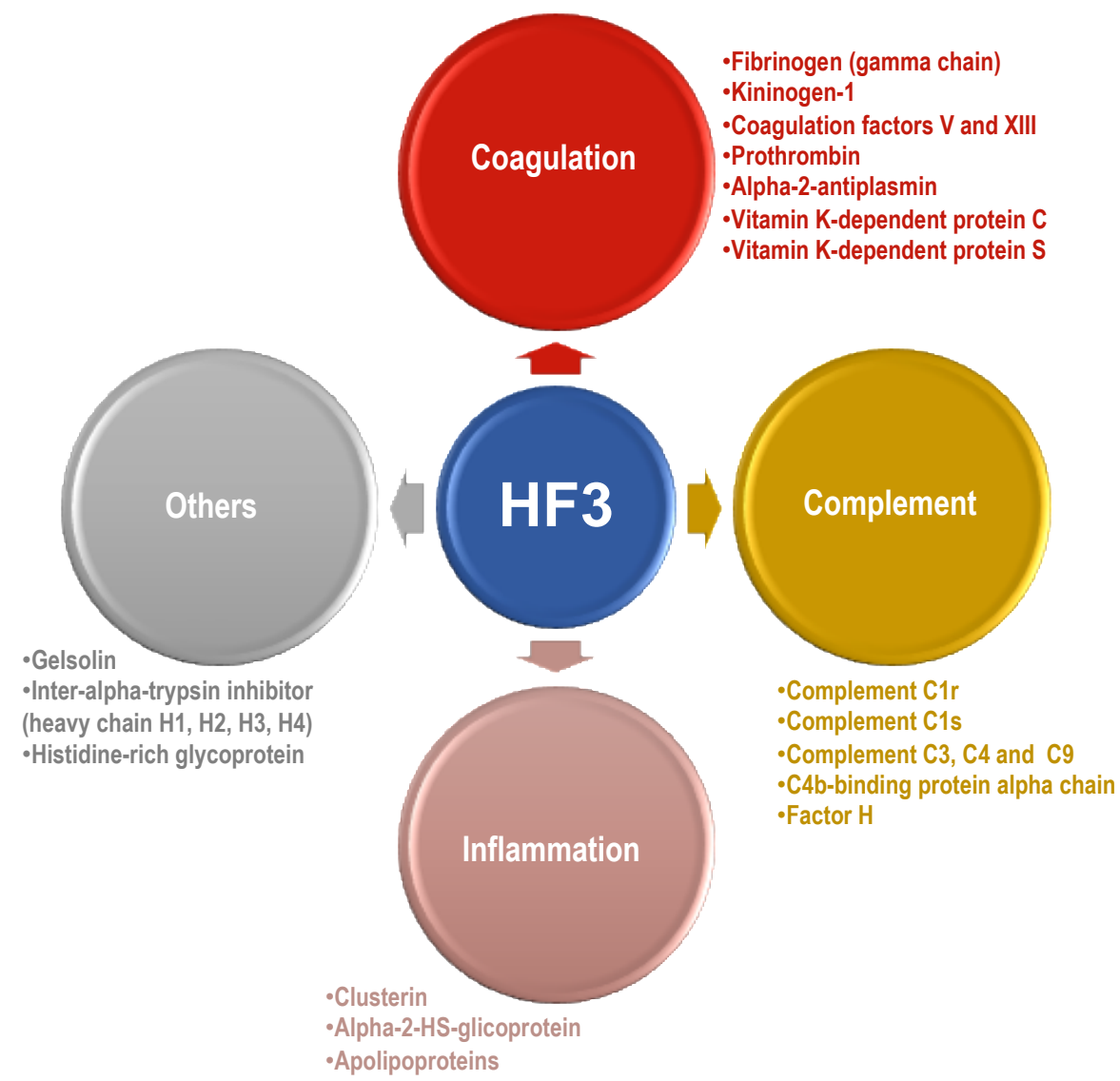

Figure 9. Schematic representation of some of the new substrates of HF3 revealed in this study, according to biological function.

The hydrolysis of human plasma proteins by an uncontrolled, exogeneous metalloproteinase has a direct impact in the plasma proteome, and it can be hypothesized that some hydrolysis products could also play synergistic roles in the pro-inflammatory and hemorrhagic processes generated by HF3.

\section{Materials and Methods}

\subsection{HF3}

HF3 (Uniprot entry Q98UF9) was purified as described previously (Oliveira et al., 2009) from B. jararaca venom provided by the Laboratory of Herpetology of Butantan Institute (São Paulo, Brazil), and identified by trypsin digestion and mass spectrometric (LC-MS/MS) analysis.

\subsection{Analytical Procedures}

Protein and peptide contents were quantified using, respectively, Bradford assay (Sigma-Aldrich, St. Louis, MO, USA) and micro-BCA assay (Pierce) kits according to the manufacturers' recommendations. SDS-PAGE was carried out according to Laemmli (1970) [106]. Silver staining was carried out according to Mortz et al., 2001 [107].

\subsection{Human Plasma}

Procedures using human blood in this study were approved by ethics committee of Instituto Federal de Educação, Ciência e Tecnologia de São Paulo, Brazil, and registered under CAAE 19892213.7.0000.5473. Human blood was collected from three volunteers who declared they had not used painkillers for at least 10 days. In order to obtain human plasma, blood was collected and anticoagulated with 0.1 vol. of $3.8 \%$ sodium citrate and 
centrifuged at $1000 \times g$ for $10 \mathrm{~min}$ at $4{ }^{\circ} \mathrm{C}$. Whole plasma samples $(\mathrm{n}=3)$ were designated as $\mathrm{P}(\mathrm{W})$.

\subsection{Albumin-Depleted Human Plasma}

To deplete serum albumin from human plasma, we employed Blue Sepharose CL-6B resin affinity chromatography (Sigma-Aldrich, St. Louis, MO, USA; $[108,109])$. Three independent experiments were carried out with plasma samples from three individuals. The procedure was performed using a microtube with a filter, according to the manufacturer's instructions. In the upper part of the filter microtube, $0.5 \mathrm{~mL}$ of resin was added, and steps for resin conditioning, binding and elution, and resin reconstitution were carried out by fractioning the total volume required in $0.5 \mathrm{~mL}$ aliquots, added to the top of the microtube, followed by mild manual agitation and centrifugation for $1 \mathrm{~min}$ at $150 \times g$, with disposal or storage of the eluted solution conducted according to the stage. The following solutions were added: (i) conditioning: $2.5 \mathrm{~mL}$ of ultrapure water and $4.0 \mathrm{~mL}$ of binding buffer (20 mM HEPES, pH 7.4), with disposal of the eluted solution; (ii) binding: the lower outlet duct of the micro tube containing the resin was closed, and $40 \mu \mathrm{L}$ of plasma diluted in $310 \mu \mathrm{L}$ of binding buffer was loaded. The tube was kept at room temperature for $30 \mathrm{~min}$ under agitation. After centrifugation, the eluted material, corresponding to the plasma depleted of albumin, was stored. For the elution of proteins bound to the resin (eluate), $4 \mathrm{~mL}$ of $2 \mathrm{M} \mathrm{NaCl}$ were added to the resin, and the eluted solution was stored. For resin reconstitution, $1 \mathrm{~mL}$ of $6 \mathrm{M}$ guanidine hydrochloride and $4 \mathrm{~mL}$ of binding buffer were applied to the resin, and the eluted solution was discarded. Albumin-depleted plasma samples were designated as $\mathrm{P}(\mathrm{Alb}-\mathrm{D})$.

\subsection{Human Plasma Depleted of 20 Most Abundant Proteins}

Depletion of the 20 most abundant proteins from human plasma was performed with the ProteoPrep 20 Plasma Immunodepletion Kit (Sigma-Aldrich, St. Louis, MO, USA), according to the manufacturer's instructions. Three independent experiments were carried out with plasma samples from three individuals. Briefly, samples of $8 \mu \mathrm{L}$ of human plasma were diluted to $100 \mu \mathrm{L}$ with phosphate-buffered saline (PBS) and loaded to a micro-spin column, previously equilibrated with PBS. After incubation for $20 \mathrm{~min}$ at room temperature, the non-bound protein fraction was recovered by centrifugation at $2000 \mathrm{rpm}$ for $1 \mathrm{~min}$ and the flow-through, containing plasma depleted of the 20 most abundant proteins $\mathrm{P}(20-\mathrm{MAP}-\mathrm{D})$, was collected in a clean tube. The remaining unbound proteins were washed twice by adding $100 \mu \mathrm{L}$ of PBS, centrifuging, and collecting the wash in the same tube. The depletion procedure was repeated five times, and flow-throughs were pooled and then concentrated using a Centricon YM-3 filter (Millipore). After each depletion procedure, the micro-spin column was regenerated with $2 \mathrm{~mL}$ of $0.1 \mathrm{M}$ Glycine- $\mathrm{HCl}, \mathrm{pH} 2.5$, and TWEEN 20 in order to elute bound proteins, and stored at $5{ }^{\circ} \mathrm{C}$ in $5 \mathrm{~mL}$ of PBS with the addition of $10 \mu \mathrm{L}$ of ProteoPrep Preservative Concentrate. Human plasma depleted of 20 most abundant proteins was designated as P(20-MAP-D).

\subsection{Human Plasma Enriched in Low-Abundance Proteins}

The enrichment of low-abundant proteins in human plasma was performed with the ProteoMiner Protein Enrichment Kit (Bio-Rad) [37] according to the manufacturer's instructions. Three independent experiments were carried out with plasma samples from three individuals. In brief, $200 \mu \mathrm{L}$ of human plasma was loaded onto the column previously conditioned with PBS, pH 7.4, and incubated for $2 \mathrm{~h}$ at room temperature. After centrifugation, the flow-through fraction was stored for further analysis. The fraction that bound to the resin, containing the low-abundant proteins, was eluted with $8 \mathrm{M}$ urea containing $2 \%$ CHAPS. For desalinization, the proteins in solution were precipitated by the addition of eight volumes of cold acetone and one volume of cold methanol, and stored for $12 \mathrm{~h}$ at $-20^{\circ} \mathrm{C}$. After centrifugation for $10 \mathrm{~min}$ at $14,000 \times \mathrm{g}$ at $4{ }^{\circ} \mathrm{C}$, the precipitate was washed 
with cold methanol and resuspended in $60 \mu \mathrm{L}$ of $100 \mathrm{mM} \mathrm{NaOH}$ and $340 \mu \mathrm{L}$ of $50 \mathrm{mM}$ HEPES, pH 7.5. Plasma enriched of low-abundant proteins was designated as P(LAP-E).

\subsection{Proteolytic Activity of HF3 on Human Plasma}

For each of the four types of human plasma preparations, three biological replicates were performed. For each experiment, P(Alb-D), P(20-MAP-D), and P(LAP-E); $50 \mu \mathrm{g}$ were separately incubated with $0.5 \mu \mathrm{g}$ HF3 $(1: 100 ; w / w)$ in $250 \mathrm{mM}$ ammonium acetate containing $\mathrm{CaCl}_{2} 1 \mathrm{mM}$ for $2 \mathrm{~h}$ at $37^{\circ} \mathrm{C}$. P(W) $(200 \mu \mathrm{g})$ was incubated with $2 \mu \mathrm{g}$ HF3 under the same conditions. Samples of $\mathrm{P}(\mathrm{Alb}-\mathrm{D}), \mathrm{P}(20-\mathrm{MAP}-\mathrm{D}), \mathrm{P}(\mathrm{LAP}-\mathrm{E})$, and $\mathrm{P}(\mathrm{W})$ were incubated without HF3, as a control, under identical conditions. Reactions were stopped by adding eight volumes of cold acetone and one volume of cold methanol, and incubated for $12 \mathrm{~h}$ at $-20^{\circ} \mathrm{C}$. Peptide fractions (supernatant) were obtained by centrifugation at $14,000 \mathrm{~g}$ for $10 \mathrm{~min}$ at $-4{ }^{\circ} \mathrm{C}$, and subsequently dried using a SpeedVac concentrator. The protein fraction (precipitate) was separated and stored at $-20{ }^{\circ} \mathrm{C}$ until use.

\subsection{LC-MS/MS Analysis of the Plasma Peptide Fraction}

Previously to LC-MS/MS analysis, plasma peptide fractions containing hydrolysis products resulting from the proteolytic activity of HF3 were subjected to removal of traces of detergent using Macro Spin Columns (Harvard Apparatus). Samples were then desalted with Sep-Pak Light C18 (Waters) cartridges, vacuum dried, and resuspended in $20 \mu \mathrm{L}$ of $0.1 \%$ formic acid. Aliquots of $10 \mu \mathrm{L}$ were separated by RP-HPLC on an EASY-nLC II (Thermo Scientific, Waltham, MA, USA) using a column $(75 \mu \mathrm{m}$ i.d. $\times 10 \mathrm{~cm})$ packed with $5 \mu \mathrm{m} \mathrm{C18}$ beads (Phenomenex), and coupled to an LTQ-Orbitrap Velos mass spectrometer (Thermo Fisher Scientific, Waltham, MA, USA). The gradient was $5-40 \%$ acetonitrile in $0.1 \mathrm{M}$ formic acid over $90 \mathrm{~min}$, at a flow rate of $300 \mathrm{~nL} / \mathrm{min}$. The mass spectrometer was operated in data dependent mode, in which one full MS scan was acquired in the $\mathrm{m} / \mathrm{z}$ range of 400-2000 at 60,000 resolution, followed by MS/MS acquisition using high-energy collision dissociation of the six most intense ions from the MS scan, at 15,000 resolution. A dynamic peak exclusion was applied to avoid the same $\mathrm{m} / \mathrm{z}$ of being selected for the next $25 \mathrm{~s}$, using a \pm 1 Da mass tolerance window around the precursor ion mass.

\subsection{Mass Spectrometry Data Analysis}

Two strategies were employed for the identification of peptides originated from HF3 cleavage of plasma proteins. In the first, we used the Mascot program, and validated the results using the PeptideProphet and ProteinProphet tools of the Trans-Proteomic Pipeline (TPP) platform (Mascot/TPP). In the second, de novo sequencing, searching the database, and validating the results were carried out using the Peaks Studio 7 program (Peaks).

Mascot/TPP: Acquired MS/MS raw data were converted to the mgf and mzXML format using MS-Convert. Database searches were performed against the human UniProtKB/ Swiss-Prot protein database (available at http:/ / www.uniprot.org; accessed on 3 February 2014) using Mascot 2.4.1 (Matrix Science) with the following parameters: no enzyme specificity indicated; $10 \mathrm{ppm}$ precursor tolerance; $20 \mathrm{mmu}$ fragment ion tolerance; variable Met oxidation (+15.9949 Da); variable $N$ terminal acetylation (+42.0105 Da); and variable Asn and Gln deamidation $(+0.9840 \mathrm{Da})$. Mascot search results were further processed using the Trans-Proteomic Pipeline (TPP, version 4.6) (Keller and Shteynberg, 2011). Peptides were included in the analysis if they were identified at a false discovery rate (FDR) of $\leq 1 \%$ at peptide level (PeptideProphet), and (ii) proteins at an FDR of $\leq 1 \%$ at protein level (ProteinProphet).

Peaks: Acquired MS/MS raw data were imported into Peaks Studio 7 software (Ma et al., 2003). De novo analysis was performed with the following parameters: no enzyme specificity indicated; $10 \mathrm{ppm}$ precursor tolerance; $0.02 \mathrm{Da}$ fragment ion tolerance; variable Met oxidation (+15.9949 Da); variable $N$ terminal acetylation (+42.0105 Da); and variable Asn and Gln deamidation (+0.9840 Da). After de novo sequencing, a database search (Peaks DB) was performed against the human UniProtKB/Swiss-Prot protein database (available 
at http:/ /www.uniprot.org; accessed on 10 February 2014), using the same parameters. Peptides were included in the analysis if they were identified at a Peaks DB FDR of $\leq 1 \%$.

\subsection{Identification of Peptides Generated the Incubation of Fibrinogen with HF3}

Fibrinogen $(50 \mu \mathrm{g})$ was incubated with HF3 $(0.5 \mu \mathrm{g})$ in $0.025 \mathrm{M}$ Tris-HCl, pH 7.5, $5 \mathrm{mM}$ $\mathrm{CaCl}_{2}$ for $2 \mathrm{~h}$ at $37^{\circ} \mathrm{C}$. The reaction was stopped by adding eight volumes of cold acetone and one volume of cold methanol, and stored for $12 \mathrm{~h}$ at $-20^{\circ} \mathrm{C}$. After centrifugation at $14,000 \times g$ for $10 \mathrm{~min}$ at $4{ }^{\circ} \mathrm{C}$, the supernatant, corresponding to the peptide fraction, was dried in a SpeedVac concentrator, subjected to desalination procedures using Sep-Pak Light C18 cartridges, vacuum dried, and resuspended in $20 \mu \mathrm{L}$ of $0.1 \%$ formic acid for analysis by LC-MS/MS, as described above, and a database search using the Peaks Studio 7 program.

\subsection{Validation of HF3 Substrates in Human Plasma by Incubation with HF3}

Apolipoprotein A-IV, clusterin, $\alpha$-2-antiplasmin, kininogen, and transthyretin $(2 \mu \mathrm{g}$; Sigma-Aldrich, St. Louis, MO, USA) were incubated with HF3 (200 ng) (1:10 (w/w) enzymeto-substrate ratio) in $0.05 \mathrm{M}$ Tris- $\mathrm{HCl}, \mathrm{pH} 8.0,1.0 \mathrm{mM} \mathrm{CaCl}_{2}$ for $2 \mathrm{~h}$ at $37^{\circ} \mathrm{C}$. Apoliprotein $\mathrm{E}$ (4 $\mu \mathrm{g}$; Sigma-Aldrich, St. Louis, MO, USA) was incubated with HF3 (400 ng) (1:10 (w/w) enzyme-to-substrate ratio) in the same buffer. A sample of each protein was incubated without enzymes under identical conditions. Reactions were stopped by adding a Laemmli sample buffer, and subjected to SDS-PAGE.

Supplementary Materials: The following are available online at https:/ / www.mdpi.com/article/10.3 390/toxins13110764/s1, Supplementary Tables S1-S8: Peptides identified by LC-MS/MS analysis of the peptide fraction of human plasma after incubation with HF3. Supplementary Table S9: Peptides identified by LC-MS/MS analysis of the peptide fraction of human fibrinogen after incubation with HF3.

Author Contributions: Conceptualization, S.M.T.S.; experimental design, A.Z., L.B. and S.M.T.S.; data collection: A.F.A.C., A.K.O., A.Z., L.B. and M.C.M.; data analysis, A.F.A., A.F.A.C., A.K.T., A.Z., L.B. and S.M.T.S.; manuscript writing, S.M.T.S.; funding acquisition, S.M.T.S.; manuscript revising, all authors. All authors have read and agreed to the published version of the manuscript.

Funding: This research was funded by São Paulo Research Foundation (FAPESP 2011/16623-1; 2011/08514-8; 2013/07467-1; 2020/12317-2) and the National Council for Scientific and Technological Development (CNPq 308133/2015-3 to SMTS).

Institutional Review Board Statement: Not applicable.

Informed Consent Statement: Not applicable.

Data Availability Statement: All mass spectrometry peptidomics data have been deposited to the ProteomeXchange Consortium (http:/ / proteomecentral.proteomexchange.org), via the PRIDE partner repository [110] with the dataset identifier: PXD027997.

Conflicts of Interest: The authors declare no conflict of interest.

\section{References}

1. Gutiérrez, J.M.; Escalante, T.; Rucavado, A.; Herrera, C. Hemorrhage caused by snake venom metalloproteinases: A journey of discovery and understanding. Toxins 2016, 8, 93. [CrossRef] [PubMed]

2. Kasturiratne, A.; Wickremasinghe, A.R.; De Silva, N.; Gunawardena, N.K.; Pathmeswaran, A.; Premaratna, R.; Savioli, L.; Lalloo, D.G.; De Silva, H.J. The global burden of snakebite: A literature analysis and modelling based on regional estimates of envenoming and deaths. PLoS Med. 2008, 5, e218. [CrossRef]

3. Ownby, C.L.; Bjarnason, J.; Tu, A.T. Hemorrhagic toxins from rattlesnake (Crotalus atrox) venom. Pathogenesis of hemorrhage induced by three purified toxins. Am. J. Pathol. 1978, 93, 201-218.

4. Ohsaka, A.; Ikezawa, H.; Kondo, H.; Kondo, S.; Uchida, N. Haemorrhagic activities of habu snake venom, and their relations to lethal toxicity, proteolytic activities and other pathological activities. Br. J. Exp. Pathol. 1960, 41, 478-486.

5. Bjarnason, J.B.; Fox, J.W. Hemorrhagic metalloproteinases from snake venoms. Pharmacol. Ther. 1994, 62, 325-372. [CrossRef]

6. White, J. Snake venoms and coagulopathy. Toxicon 2005, 45, 951-967. [CrossRef]

7. Isbister, G. Procoagulant snake toxins: Laboratory studies, diagnosis, and understanding snakebite coagulopathy. Semin. Thromb. Hemost. 2009, 35, 93-103. [CrossRef] [PubMed] 
8. Fox, J.W.; Serrano, S.M.T. Insights into and speculations about snake venom metalloproteinase (SVMP) synthesis, folding and disulfide bond formation and their contribution to venom complexity. FEBS J. 2008, 275, 3016-3030. [CrossRef]

9. Oliveira, A.K.; Leme, A.P.; Asega, A.F.; Camargo, A.C.M.; Fox, J.W.; Serrano, S.M.T. New insights into the structural elements involved in the skin haemorrhage induced by snake venom metalloproteinases. Thromb. Haemost. 2010, 104, 485-497. [CrossRef] [PubMed]

10. Escalante, T.; Rucavado, A.; Fox, J.W.; Gutiérrez, J.M. Key events in microvascular damage induced by snake venom hemorrhagic metalloproteinases. J. Proteom. 2011, 74, 1781-1794. [CrossRef]

11. Kini, R.M.; Koh, C.Y. Metalloproteases Affecting blood coagulation, fibrinolysis and platelet aggregation from snake venoms: Definition and nomenclature of interaction sites. Toxins 2016, 8, 284. [CrossRef]

12. Assakura, M.T.; Reichl, A.P.; Mandelbaum, F.R. Comparison of immunological, biochemical and biophysical properties of three hemorrhagic factors isolated from the venom of Bothrops jararaca (jararaca). Toxicon 1986, 24, 943-946. [CrossRef]

13. Oliveira, A.K.; Leme, A.F.P.; Assakura, M.T.; Menezes, M.C.; Zelanis, A.; Tashima, A.K.; Lopes-Ferreira, M.; Lima, C.; Camargo, A.C.; Fox, J.W.; et al. Simplified procedures for the isolation of HF3, bothropasin, disintegrin-like/cysteine-rich protein and a novel P-I metalloproteinase from Bothrops jararaca venom. Toxicon 2009, 53, 797-801. [CrossRef]

14. Silva, C.A.; Zuliani, J.P.; Assakura, M.T.; Mentele, R.; Camargo, A.C.; Teixeira, C.F.; Serrano, S.M. Activation of $\alpha M \beta 2-m e d i a t e d$ phagocytosis by HF3, a P-III class metalloproteinase isolated from the venom of Bothrops jararaca. Biochem. Biophys. Res. Commun. 2004, 322, 950-956. [CrossRef] [PubMed]

15. Asega, A.F.; Menezes, M.C.; Trevisan-Silva, D.; Carvalho, D.C.; Bertholim, L.; Oliveira, A.K.; Zelanis, A.; Serrano, S.M.T. Cleavage of proteoglycans, plasma proteins and the platelet-derived growth factor receptor in the hemorrhagic process induced by snake venom metalloproteinases. Sci. Rep. 2020, 10, 12912. [CrossRef] [PubMed]

16. Asega, A.F.; Oliveira, A.K.; Menezes, M.C.; Neves-Ferreira, A.G.C.; Serrano, S.M. Interaction of Bothrops jararaca venom metalloproteinases with protein inhibitors. Toxicon 2014, 80, 1-8. [CrossRef] [PubMed]

17. Menezes, M.C.; de Oliveira, A.K.; Melo, R.L.; Lopes-Ferreira, M.; Rioli, V.; Balan, A.; Leme, A.F.P.; Serrano, S.M. Disintegrinlike/cysteine-rich domains of the reprolysin HF3: Site-directed mutagenesis reveals essential role of specific residues. Biochimie 2011, 93, 345-351. [CrossRef]

18. Menezes, M.C.; Imbert, L.; Kitano, E.S.; Vernet, T.; Serrano, S.M.T. Recombinant expression of the precursor of the hemorrhagic metalloproteinase HF3 and its non-catalytic domains using a cell-free synthesis system. Amino Acids 2016, 48, 2205-2214. [CrossRef] [PubMed]

19. Leme, A.P.; Sherman, N.; Smalley, D.M.; Sizukusa, L.O.; Oliveira, A.K.; Menezes, M.C.; Fox, J.W.; Serrano, S.M.T. Hemorrhagic activity of HF3, a snake venom metalloproteinase: Insights from the proteomic analysis of mouse skin and blood plasma. J. Proteome Res. 2012, 11, 279-291. [CrossRef]

20. Zelanis, A.; Oliveira, A.K.; Prudova, A.; Huesgen, P.F.; Tashima, A.K.; Kizhakkedathu, J.; Overall, C.M.; Serrano, S.M.T. Deep profiling of the cleavage specificity and human substrates of snake venom metalloprotease HF3 by proteomic identification of cleavage site specificity (PICS) using proteome derived peptide libraries and terminal amine isotopic labeling of substrates. J. Proteome Res. 2019, 18, 3419-3428. [CrossRef]

21. Bertholim, L.; Zelanis, A.; Oliveira, A.K.; Serrano, S.M.T. Proteome-derived peptide library for the elucidation of the cleavage specificity of HF3, a snake venom metalloproteinase. Amino Acids 2016, 48, 1331-1335. [CrossRef]

22. Leme, A.P.; Escalante, T.; Pereira, J.G.; Oliveira, A.K.; Sanchez, E.O.F.; Gutiérrez, J.M.; Serrano, S.M.T.; Fox, J.W. High resolution analysis of snake venom metalloproteinase (SVMP) peptide bond cleavage specificity using proteome based peptide libraries and mass spectrometry. J. Proteom. 2011, 74, 401-410. [CrossRef] [PubMed]

23. Anderson, N.L.; Anderson, N.G. The human plasma proteome. Mol. Cell. Proteom. 2002, 1, 845-867. [CrossRef]

24. Geyer, P.E.; Kulak, N.A.; Pichler, G.; Holdt, L.M.; Teupser, D.; Mann, M. Plasma Proteome profiling to assess human health and disease. Cell Syst. 2016, 2, 185-195. [CrossRef]

25. Szklarczyk, D.; Morris, J.H.; Cook, H.; Kuhn, M.; Wyder, S.; Simonovic, M.; Santos, A.; Doncheva, N.T.; Roth, A.; Bork, P.; et al. The STRING database in 2017: Quality-controlled protein-protein association networks, made broadly accessible. Nucleic Acids Res. 2017, 45, D362-D368. [CrossRef]

26. Schechter, I.; Berger, A. On the size of the active site in proteases. I. Papain. Biochem. Biophys. Res. Commun. 1967, $27,157-162$. [CrossRef]

27. Schilling, O.; Huesgen, P.; Barré, O.; Keller, U.A.D.; Overall, C.M. Characterization of the prime and non-prime active site specificities of proteases by proteome-derived peptide libraries and tandem mass spectrometry. Nat. Protoc. 2011, 6, 111-120. [CrossRef] [PubMed]

28. Kloczewiak, M.; Timmons, S.; Lukas, T.J.; Hawiger, J. Platelet receptor recognition site on human fibrinogen. Synthesis and structure-function relationship of peptides corresponding to the carboxy-terminal segment of the gamma chain. Biochemistry 1984, 23, 1767-1774. [CrossRef]

29. Chen, R.; Doolittle, R.F. Isolation, Characterization, and location of a donor-acceptor unit from cross-linked fibrin. Proc. Natl. Acad. Sci. USA 1970, 66, 472-479. [CrossRef]

30. Packham, M.A.; Taylor, D.M.; Yeo, E.L.; Gemmell, C.H.; Patil, S.; Lam, S.C.-T.; Rand, M.L. The fibrinogen $\gamma$ chain dodecapeptide inhibits agonist-induced aggregation of rabbit platelets and fibrinogen binding to rabbit glycoprotein IIb-IIIa. Thromb. Haemost. 1999, 82, 1680-1686. [CrossRef] 
31. Millioni, R.; Tolin, S.; Puricelli, L.; Sbrignadello, S.; Fadini, G.P.; Tessari, P.; Arrigoni, G. High Abundance proteins depletion vs low abundance proteins enrichment: Comparison of methods to reduce the plasma proteome complexity. PLoS ONE 2011, 6, e19603. [CrossRef] [PubMed]

32. Hakimi, A.; Auluck, J.; Jones, G.D.D.; Ng, L.L.; Jones, D.J.L. Assessment of reproducibility in depletion and enrichment workflows for plasma proteomics using label-free quantitative data-independent LC-MS. Proteomics 2014, 14, 4-13. [CrossRef]

33. Polaskova, V.; Kapur, A.; Khan, A.; Molloy, M.; Baker, M.S. High-abundance protein depletion: Comparison of methods for human plasma biomarker discovery. Electrophoresis 2010, 31, 471-482. [CrossRef]

34. Govorukhina, N.; Keizer-Gunnink, A.; van der Zee, A.; de Jong, S.; de Bruijn, H.; Bischoff, R. Sample preparation of human serum for the analysis of tumor markers. J. Chromatogr. A 2003, 1009, 171-178. [CrossRef]

35. Gong, Y.; Li, X.; Yang, B.; Ying, W.; Li, D.; Zhang, Y.; Dai, S.; Cai, Y.; Wang, J.; He, A.F.; et al. Different immunoaffinity fractionation strategies to characterize the human plasma proteome. J. Proteome Res. 2006, 5, 1379-1387. [CrossRef] [PubMed]

36. Quero, C.; Colomé, N.; Prieto, M.R.; Carrascal, M.; Posada, M.; Gelpí, E.; Abian, J. Determination of protein markers in human serum: Analysis of protein expression in toxic oil syndrome studies. Proteomics 2004, 4, 303-315. [CrossRef] [PubMed]

37. Boschetti, E.; Righetti, P.G. The ProteoMiner in the proteomic arena: A non-depleting tool for discovering low-abundance species. J. Proteom. 2008, 71, 255-264. [CrossRef]

38. Guerranti, R.; Cortelazzo, A.; Hope-Onyekwere, N.S.; Furlani, E.; Cerutti, H.; Puglia, M.; Bini, L.; Leoncini, R. In vitro effects of Echis carinatus venom on the human plasma proteome. Proteomics 2010, 10, 3712-3722. [CrossRef] [PubMed]

39. Hwang, I.K.; Park, S.M.; Kim, S.Y.; Lee, S.-T. A proteomic approach to identify substrates of matrix metalloproteinase-14 in human plasma. Biochim. Biophys. Acta Proteins Proteom. 2004, 1702, 79-87. [CrossRef]

40. Escalante, T.; Rucavado, A.; Pinto, A.F.M.; Terra, R.M.S.; Gutiérrez, J.M.; Fox, J.W. Wound exudate as a proteomic window to reveal different mechanisms of tissue damage by snake venom toxins. J. Proteome Res. 2009, 8, 5120-5131. [CrossRef]

41. Menezes, M.C.; Kitano, E.S.; Bauer, V.C.; Oliveira, A.K.; Cararo-Lopes, E.; Nishiyama, M.Y.; Zelanis, A.; Serrano, S.M. Early response of $\mathrm{C} 2 \mathrm{C} 12$ myotubes to a sub-cytotoxic dose of hemorrhagic metalloproteinase HF3 from Bothrops jararaca venom. $J$. Proteom. 2019, 198, 163-176. [CrossRef]

42. Zhang, J.; Xin, L.; Shan, B.; Chen, W.; Xie, M.; Yuen, D.; Zhang, W.; Zhang, Z.; Lajoie, G.A.; Ma, B. PEAKS DB: De novo sequencing assisted database search for sensitive and accurate peptide identification. Mol. Cell. Proteomics 2012, 11, M111.010587. [CrossRef] [PubMed]

43. Eckhard, U.; Huesgen, P.F.; Schilling, O.; Bellac, C.L.; Butler, G.S.; Cox, J.H.; Dufour, A.; Goebeler, V.; Kappelhoff, R.; Keller, U.A.D.; et al. Active site specificity profiling of the matrix metalloproteinase family: Proteomic identification of 4300 cleavage sites by nine MMPs explored with structural and synthetic peptide cleavage analyses. Matrix Biol. 2016, 49, 37-60. [CrossRef]

44. Kleifeld, O.; Doucet, A.; Keller, U.A.D.; Prudova, A.; Schilling, O.; Kainthan, R.K.; Starr, A.E.; Foster, L.J.; Kizhakkedathu, J.N.; Overall, C.M. Isotopic labeling of terminal amines in complex samples identifies protein N-termini and protease cleavage products. Nat. Biotechnol. 2010, 28, 281-288. [CrossRef] [PubMed]

45. Prudova, A.; Keller, U.A.D.; Butler, G.S.; Overall, C.M. Multiplex N-terminome analysis of MMP-2 and MMP-9 substrate degradomes by iTRAQ-TAILS quantitative proteomics. Mol. Cell. Proteom. 2010, 9, 894-911. [CrossRef]

46. Schlage, P.; Egli, F.E.; Nanni, P.; Wang, L.W.; Kizhakkedathu, J.N.; Apte, S.; Keller, U.A.D. Time-resolved analysis of the matrix metalloproteinase 10 substrate degradome. Mol. Cell. Proteom. 2014, 13, 580-593. [CrossRef]

47. Kloczewiak, M.; Timmons, S.; Bednarek, M.A.; Sakon, M.; Hawiger, J. Platelet receptor recognition domain on the .gamma. chain of human fibrinogen and its synthetic peptide analogues. Biochemistry 1989, 28, 2915-2919. [CrossRef]

48. Springer, T.A.; Zhu, J.; Xiao, T. Structural basis for distinctive recognition of fibrinogen $\gamma \mathrm{C}$ peptide by the platelet integrin $\alpha \mathrm{Illb} \beta$. J. Cell Biol. 2008, 182, 791-800. [CrossRef] [PubMed]

49. Farrell, D.H.; Thiagarajan, P.; Chung, D.W.; Davie, E.W. Role of fibrinogen alpha and gamma chain sites in platelet aggregation. Proc. Natl. Acad. Sci. USA 1992, 89, 10729-10732. [CrossRef]

50. Stockley, R.A. The multiple facets of alpha-1-antitrypsin. Ann. Transl. Med. 2015, 3, 130-137. [CrossRef]

51. Robbins, K.C.; Summaria, L.; Hsieh, B.; Shah, R.J. The peptide chains of human plasmin. Mechanism of activation of human plasminogen to plasmin. J. Biol. Chem. 1967, 242, 2333-2342. [CrossRef]

52. O'Reilly, M.S. Angiostatin: A novel angiogenesis inhibitor that mediates the suppression of metastases by a lewis lung carcinoma. Cell 1994, 79, 315-328. [CrossRef]

53. Cao, Y.; Xue, L. Angiostatin. Semin. Thromb. Hemost. 2004, 30, 83-93. [CrossRef]

54. Cornelius, A.L.; Nehring, L.C.; Harding, E.; Bolanowski, M.; Welgus, H.G.; Kobayashi, D.K.; Pierce, R.A.; Shapiro, S.D. Matrix metalloproteinases generate angiostatin: Effects on neovascularization. J. Immunol. 1998, 161, 6845-6852.

55. Ho, P.L.; Serrano, S.M.T.; Chudzinski-Tavassi, A.M.; Moura-Da-Silva, A.M.; Mentele, R.; Caldas, C.; Oliva, M.L.V.; Batista, I.D.F.C.; de Oliveira, M.L.S. Angiostatin-like molecules are generated by snake venom metalloproteinases. Biochem. Biophys. Res. Commun. 2002, 294, 879-885. [CrossRef]

56. Moroi, M.; Aoki, N. Isolation and characterization of alpha2-plasmin inhibitor from human plasma. A novel proteinase inhibitor which inhibits activator-induced clot lysis. J. Biol. Chem. 1976, 251, 5956-5965. [CrossRef]

57. Lee, K.N.; Lee, C.S.; Tae, W.-C.; Jackson, K.W.; Christiansen, V.J.; Mckee, P.A. Crosslinking of $\alpha 2$-Antiplasmin to Fibrin. Ann. N. Y. Acad. Sci. 2006, 936, 335-339. [CrossRef] 
58. Koyama, T.; Koike, Y.; Toyota, S.; Miyagi, F.; Suzuki, N.; Aoki, N. Different NH2-terminal form with 12 additional residues of «2-plasmin inhibitor from human plasma and culture media of HEP G2 cells. Biochem. Biophys. Res. Commun. 1994, 200, 417-422. [CrossRef]

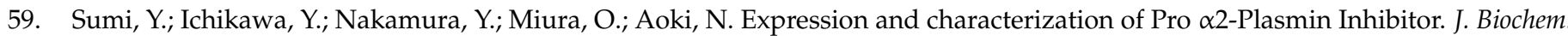
1989, 106, 703-707. [CrossRef] [PubMed]

60. Muszbek, L.; Bereczky, Z.; Bagoly, Z.; Komáromi, I.; Katona, É. Factor XIII: A coagulation factor with multiple plasmatic and cellular functions. Physiol. Rev. 2011, 91, 931-972. [CrossRef]

61. Pisano, J.J.; Finlayson, J.S.; Peyton, M.P. Cross-link in fibrin polymerized by Factor XIII: Egr-(ggr-Glutamyl) lysine. Science 1968, 160, 892-893. [CrossRef] [PubMed]

62. Komáromi, I.; Bagoly, Z.; Muszbek, L. Factor XIII: Novel structural and functional aspects. J. Thromb. Haemost. 2011, 9, 9-20. [CrossRef] [PubMed]

63. Kitamura, N.; Kitagawa, H.; Fukushima, D.; Takagaki, Y.; Miyata, T.; Nakanishi, S. Structural organization of the human kininogen gene and a model for its evolution. J. Biol. Chem. 1985, 260, 8610-8617. [CrossRef]

64. Salvesen, G.; Parkes, C.; Abrahamson, M.; Grubb, A.; Barrett, A.J. Human low-Mr kininogen contains three copies of a cystatin sequence that are divergent in structure and in inhibitory activity for cysteine proteinases. Biochem. J. 1986, 234, 429-434. [CrossRef] [PubMed]

65. Kaplan, A.P.; Silverberg, M. The coagulation-kinin pathway of human plasma. Blood 1987, 70, 1-15. [CrossRef]

66. Thompson, E.R.; Mandle, R.; Kaplan, A.P. Characterization of human high molecular weight kininogen. Procoagulant activity associated with the light chain of kinin-free high molecular weight kininogen. J. Exp. Med. 1978, 147, 488-499. [CrossRef] [PubMed]

67. Kato, H.; Sugo, T.; Ikari, N.; Hashimoto, N.; Maruyama, I.; Han, Y.N.; Iwanaga, S.; Fujii, S. Role of bovine high-molecular-weight (HMW) kininogen in contact-mediated activation of bovine Factor XII. Adv. Exp. Med. Biol. 1979, 120, 19-37.

68. Zaitsev, V.N.; Zaitseva, I.; Papiz, M.; Lindley, P.F. An X-ray crystallographic study of the binding sites of the azide inhibitor and organic substrates to ceruloplasmin, a multi-copper oxidase in the plasma. JBIC J. Biol. Inorg. Chem. 1999, 4, 579-587. [CrossRef] [PubMed]

69. Ehrenwald, E.; Fox, P. Isolation of nonlabile human ceruloplasmin by chromatographic removal of a plasma metalloproteinase. Arch. Biochem. Biophys. 1994, 309, 392-395. [CrossRef] [PubMed]

70. Gitlin, J.D. Transcriptional regulation of ceruloplasmin gene expression during inflammation. J. Biol. Chem. 1988, 263, 6281-6287. [CrossRef]

71. Fleming, R.E.; Whitman, I.P.; Gitlin, J.D. Induction of ceruloplasmin gene expression in rat lung during inflammation and hyperoxia. Am. J. Physiol. Cell. Mol. Physiol. 1991, 260, L68-L74. [CrossRef]

72. Walker, F.J.; Fay, P.J. Characterization of an interaction between protein C and ceruloplasmin. J. Biol. Chem. 1990, 265, 1834-1836. [CrossRef]

73. Reid, K.B.M.; Porter, R.R. The proteolytic activation systems of complement. Annu. Rev. Biochem. 1981, 50, 433-464. [CrossRef]

74. Fearon, D.T.; Carroll, M.C. Regulation of B lymphocyte responses to foreign and self-antigens by the CD19/CD21 complex. Annu. Rev. Immunol. 2000, 18, 393-422. [CrossRef] [PubMed]

75. Carroll, M.C. The complement system in regulation of adaptive immunity. Nat. Immunol. 2004, 5, 981-986. [CrossRef]

76. Arlaud, G.J.; Volanakis, J.E.; Thielens, N.M.; Narayana, S.V.; Rossi, V.; Xu, Y. The Atypical serine proteases of the complement system. Adv. Immunol. 1998, 69, 249-307. [CrossRef]

77. Vogel, C.-W.; Müller-Eberhard, H.J. The cobra complement system: I. The alternative pathway of activation. Dev. Comp. Immunol. 1985, 9, 311-325. [CrossRef]

78. Tambourgi, D.; van den Berg, C.W. Animal venoms/toxins and the complement system. Mol. Immunol. 2014, 61, 153-162. [CrossRef]

79. Jeong, S.; Ledee, D.; Gordon, G.M.; Itakura, T.; Patel, N.; Martin, A.; Fini, M.E. Interaction of Clusterin and matrix metalloproteinase-9 and its implication for epithelial homeostasis and inflammation. Am. J. Pathol. 2012, 180, 2028-2039. [CrossRef]

80. Mori, K.; Emoto, M.; Inaba, M. Fetuin-A: A multifunctional protein. Recent Pat. Endocr. Metab. Immune Drug Discov. 2011, 5, 124-146. [CrossRef]

81. Wang, H.; Zhang, M.; Soda, K.; Sama, A.; Tracey, K.J. Fetuin protects the fetus from TNF. Lancet 1997, 350, 861-862. [CrossRef]

82. Ombrellino, M.; Wang, H.; Yang, H.; Zhang, M.; Vishnubhakat, J.; Frazier, A.; Scher, L.A.; Friedman, S.G.; Tracey, K.J. Fetuin, a negative acute phase protein, attenuates TNF synthesis and the innate inflammatory response to carrageenan. Shock 2001, 15, 181-185. [CrossRef] [PubMed]

83. Hedrich, J.; Lottaz, D.; Meyer, K.; Yiallouros, I.; Jahnen-Dechent, W.; Stöcker, W.; Becker-Pauly, C. Fetuin-A and cystatin C are endogenous inhibitors of human meprin metalloproteases. Biochemistry 2010, 49, 8599-8607. [CrossRef] [PubMed]

84. Dholey, Y.; Chaudhuri, A.; Chakraborty, S.S. An integrated in silico approach to understand protein-protein interactions: Human meprin- $\beta$ with fetuin-A. J. Biomol. Struct. Dyn. 2020, 38, 2080-2092. [CrossRef] [PubMed]

85. Gisterå, A.; Hansson, G.K. The immunology of atherosclerosis. Nat. Rev. Nephrol. 2017, 13, 2368-2380. [CrossRef]

86. Kim, M.-S.; Pinto, S.M.; Getnet, D.; Nirujogi, R.S.; Manda, S.S.; Chaerkady, R.; Madugundu, A.K.; Kelkar, D.S.; Isserlin, R.; Jain, S.; et al. A draft map of the human proteome. Nature 2014, 509, 575-581. [CrossRef] 
87. Kim, S.Y.; Park, S.M.; Lee, S.-T. Apolipoprotein C-II is a novel substrate for matrix metalloproteinases. Biochem. Biophys. Res. Commun. 2006, 339, 47-54. [CrossRef]

88. Park, J.Y.; Park, J.H.; Jang, W.; Hwang, I.-K.; Kim, I.J.; Kim, H.-J.; Cho, K.-H.; Lee, S.-T. Apolipoprotein A-IV is a novel substrate for matrix metalloproteinases. J. Biochem. 2012, 151, 291-298. [CrossRef]

89. El-Asmar, M.; Swaney, J. Proteolysis in vitro of low and high density lipoproteins in human plasma by Cerastes cerastes (Egyptian sand viper) venom. Toxicon 1988, 26, 809-816. [CrossRef]

90. Lind, S.E.; Smith, D.B.; Janmey, P.A.; Stossel, T.P. Role of plasma gelsolin and the vitamin D-binding protein in clearing actin from the circulation. J. Clin. Investig. 1986, 78, 736-742. [CrossRef]

91. Haddad, J.G.; Harper, K.D.; Guoth, M.; Pietra, G.G.; Sanger, J.W. Angiopathic consequences of saturating the plasma scavenger system for actin. Proc. Natl. Acad. Sci. USA 1990, 87, 1381-1385. [CrossRef] [PubMed]

92. Epstein, F.H.; Lee, W.M.; Galbraith, R.M. The extracellular actin-scavenger system and actin toxicity. N. Engl. J. Med. 1992, 326, 1335-1341. [CrossRef] [PubMed]

93. Park, S.-M.; Hwang, I.K.; Kim, S.Y.; Lee, S.-J.; Park, K.-S.; Lee, S.-T. Characterization of plasma gelsolin as a substrate for matrix metalloproteinases. Proteomics 2006, 6, 1192-1199. [CrossRef]

94. Zhuo, L.; Hascall, V.C.; Kimata, K. Inter- $\alpha$-trypsin Inhibitor, a covalent protein-glycosaminoglycan-protein complex. J. Biol. Chem. 2004, 279, 38079-38082. [CrossRef]

95. Lord, M.S.; Melrose, J.; Day, A.J.; Whitelock, J.M. The inter- $\alpha$-trypsin inhibitor family: Versatile molecules in biology and pathology. J. Histochem. Cytochem. 2020, 68, 907-927. [CrossRef]

96. Fries, E.; Blom, A. Bikunin-Not just a plasma proteinase inhibitor. Int. J. Biochem. Cell Biol. 2000, 32, 125-137. [CrossRef]

97. Bost, F.; Diarra-Mehrpour, M.; Martin, J.-P. Inter-alpha-trypsin inhibitor proteoglycan family. A group of proteins binding and stabilizing the extracellular matrix. Eur. J. Biochem. 1998, 252, 339-346. [CrossRef] [PubMed]

98. Zhuo, L.; Kimata, K. Structure and function of inter- $\alpha$-trypsin inhibitor heavy chains. Connect. Tissue Res. 2008, 49, 311-320. [CrossRef]

99. He, H.; Zhang, S.; Tighe, S.; Son, J.; Tseng, S.C.G. Immobilized heavy chain-hyaluronic acid polarizes lipopolysaccharide-activated macrophages toward M2 phenotype. J. Biol. Chem. 2013, 288, 25792-25803. [CrossRef]

100. Catanese, J.J.; Kress, L.F. Enzymatic digestion of human plasma inter- $\alpha$-trypsin inhibitor by snake venom metalloproteinases. Comp. Biochem. Physiol. Part B Comp. Biochem. 1985, 80, 507-512. [CrossRef]

101. Jones, A.L.; Hulett, M.; Parish, C.R. Histidine-rich glycoprotein: A novel adaptor protein in plasma that modulates the immune, vascular and coagulation systems. Immunol. Cell Biol. 2005, 83, 106-118. [CrossRef]

102. Poon, I.; Patel, K.K.; Davis, D.A.S.; Parish, C.; Hulett, M. Histidine-rich glycoprotein: The Swiss Army knife of mammalian plasma. Blood 2011, 117, 2093-2101. [CrossRef] [PubMed]

103. Leung, L.; Saigo, K.; Grant, D. Heparin binds to human monocytes and modulates their procoagulant activities and secretory phenotypes. Effects of histidine-rich glycoprotein. Blood 1989, 73, 177-184. [CrossRef]

104. Borza, D.-B.; Morgan, W.T. Acceleration of plasminogen activation by tissue plasminogen activator on surface-bound histidineproline-rich glycoprotein. J. Biol. Chem. 1997, 272, 5718-5726. [CrossRef] [PubMed]

105. Lijnen, H.; Hoylaerts, M.; Collen, D. Isolation and characterization of a human plasma protein with affinity for the lysine binding sites in plasminogen. Role in the regulation of fibrinolysis and identification as histidine-rich glycoprotein. J. Biol. Chem. 1980, 255, 10214-10222. [CrossRef]

106. Laemmli, U.K. Cleavage of Structural Proteins during the Assembly of the Head of Bacteriophage T4. Nature 1970, 227, 680-685. [CrossRef] [PubMed]

107. Mortz, E.; Krogh, T.N.; Vorum, H.; Görg, A. Improved silver staining protocols for high sensitivity protein identification using matrix-assisted laser desorption/ionization-time of flight analysis. Proteomics 2001, 1, 1359-1363. [CrossRef]

108. Travis, J.; Pannell, R. Selective removal of albumin from plasma by affinity chromatography. Clin. Chim. Acta 1973, 49, 49-52. [CrossRef]

109. Subramanian, S.; Ross, P.D. Dye-ligand affinity chromatography: The interaction of cibacron blue F3GA ${ }^{\circledR}$ with Proteins and Enzyme. Crit. Rev. Biochem. 1984, 16, 169-205. [CrossRef]

110. Vizcaíno, J.A.; Deutsch, E.W.; Wang, R.; Csordas, A.; Reisinger, F.; Ríos, D.; Dianes, J.A.; Sun, Z.; Farrah, T.; Bandeira, N.; et al. ProteomeXchange provides globally coordinated proteomics data submission and dissemination. Nat. Biotechnol. 2014, 32, 223-226. [CrossRef] 